\title{
Intracellular Transport and Cytotoxicity of the Protein Toxin Ricin
}

\author{
Natalia Sowa-Rogozińska ${ }^{1}{ }^{(0)}$, Hanna Sominka ${ }^{1}\left(\mathbb{D}\right.$, Jowita Nowakowska-Gołacka ${ }^{1}(\mathbb{D}$, \\ Kirsten Sandvig 2,3(1) and Monika Słomińska-Wojewódzka ${ }^{1, *}$ (1) \\ 1 Department of Medical Biology and Genetics, Faculty of Biology, University of Gdańsk, Wita Stwosza 59, \\ 80-308 Gdańsk, Poland; natalia.sowa@phdstud.ug.edu.pl (N.S.-R.); \\ hanna.sominka@phdstud.ug.edu.pl (H.S.); jowita.nowakowska@phdstud.ug.edu.pl (J.N.-G.) \\ 2 Department of Molecular Cell Biology, Institute for Cancer Research, Oslo University Hospital, \\ 0379 Oslo, Norway; kirsten.sandvig@ibv.uio.no \\ 3 Faculty of Mathematics and Natural Sciences, Department of Biosciences, University of Oslo, \\ 0316 Oslo, Norway \\ * Correspondence: monika.slominska@biol.ug.edu.pl; Tel.: +48-585-236-035
}

Received: 22 May 2019; Accepted: 14 June 2019; Published: 18 June 2019

\begin{abstract}
Ricin can be isolated from the seeds of the castor bean plant (Ricinus communis). It belongs to the ribosome-inactivating protein (RIP) family of toxins classified as a bio-threat agent due to its high toxicity, stability and availability. Ricin is a typical A-B toxin consisting of a single enzymatic A subunit (RTA) and a binding B subunit (RTB) joined by a single disulfide bond. RTA possesses an RNA N-glycosidase activity; it cleaves ribosomal RNA leading to the inhibition of protein synthesis. However, the mechanism of ricin-mediated cell death is quite complex, as a growing number of studies demonstrate that the inhibition of protein synthesis is not always correlated with long term ricin toxicity. To exert its cytotoxic effect, ricin A-chain has to be transported to the cytosol of the host cell. This translocation is preceded by endocytic uptake of the toxin and retrograde traffic through the trans-Golgi network (TGN) and the endoplasmic reticulum (ER). In this article, we describe intracellular trafficking of ricin with particular emphasis on host cell factors that facilitate this transport and contribute to ricin cytotoxicity in mammalian and yeast cells. The current understanding of the mechanisms of ricin-mediated cell death is discussed as well. We also comment on recent reports presenting medical applications for ricin and progress associated with the development of vaccines against this toxin.
\end{abstract}

Keywords: ricin; protein synthesis inhibition; apoptosis

Key Contribution: This review summarizes the current knowledge of ricin intracellular transport and mechanisms of its cytotoxicity.

\section{Introduction}

The toxin ricin is a naturally occurring, extremely toxic protein isolated from the seeds of the castor plant, Ricinus communis. This toxin was first described in 1888 by Peter Hermann Stillmark, who identified the active ingredient isolated from the castor seeds as a protein [1]. Interestingly, he described in his doctoral thesis, ricin's agglutinating properties, being the first person who defined and characterized a specific carbohydrate-binding protein, that later was called lectin [2]. At that time, the ability of extracts from Ricinus communis to agglutinate erythrocytes and to precipitate serum proteins was considered to be the mechanism behind the cytotoxic action of ricin. Later experiments showed that the toxicity and agglutination effects are separate properties of this toxin [3]. The structure 
of ricin was described by Olsnes and Pihl [4]. They also found that ricin exerts its cytotoxic effect by enzymatic action on eukaryotic ribosomes resulting in inhibition of protein synthesis [3-5]. Considering the mechanism of ricin cytotoxic activity, it was the very first identified RIP (ribosome-inactivating protein) assigned to the class II of this group of protein toxins [6-8].

Ricin belongs to the A-B family of protein toxins. The A-chain (RTA, $\sim 32 \mathrm{kDa}$ ) is linked by a single disulfide bond to the lectin B-chain (RTB, $\sim 34 \mathrm{kDa}$ ). Together they form ricin holotoxin (Figure 1). RTA possesses an enzymatic activity [6,7], whereas RTB binds to eukaryotic cell-surface glycoproteins and glycolipids [9]. Ricin A-chain specifically depurinates the $\alpha$-sarcin-ricin loop (SRL) by hydrolyzing the $\mathrm{N}$-glycosidic bond at adenine 4324 located at a GAGA hairpin of SRL of the 28S rRNA in the eukaryotic large ribosomal subunit [5], (for review see Refs. [8,10,11]). Interestingly, ricin does not remove an adenine from rRNA in whole E. coli ribosomes, thus genes coding for ricin could be expressed in E. coli [12]. It is considered that the sarcin-ricin loop is one the largest universally-conserved regions of the ribosome $[13,14]$. This highlights its importance in ribosome function. Indeed, SRL significantly influences the proper assembly of the functional structure of the 50S prokaryotic subunit [15], and it is highly probable that this loop fulfills a similar role in the large ribosomal subunit in eukaryotic cells. However, what is most important for ricin toxicity is that depurination of SRL prevents the binding of two crucial factors operating in the machinery of protein synthesis: the eukaryotic elongation factor 1 (eEF-1) and the elongation factor 2 (eEF-2) $[9,16,17]$. This blocks protein synthesis and is a prerequisite for the cytotoxic effect of ricin. A single ricin A-chain molecule is able to inactivate approximately 1500 ribosomes per minute [18,19]. It happens much faster than the cell can produce new ones [20]. Ricin's lethal dose in humans was estimated to be about $1.78 \mathrm{mg}$ for an average adult [21]. However, its toxicity depends on the route of exposure. Inhalation is more potent than oral administration. The inhalation median lethal dose (LD50) is 3-5 $\mu \mathrm{g} / \mathrm{kg}$, while the oral LD50 is $20 \mathrm{mg} / \mathrm{kg}$ [22]. Due to ricin's high toxicity and stability, ease of production and good availability, it has been classified by the US Centers for Disease Control and Prevention (CDC) as a Category B Select Agent. Implementation of the Chemical Weapons Convention (CWC) in the national legislation of the 192 signatory countries (June 2017) makes undeclared ricin purification a global crime [23]. Despite the fact that ricin-mediated depurination of rRNA has been quite well described, other mechanisms involved in its cytotoxicity are not completely clarified. In fact, the inhibition of protein synthesis by ricin A-chain is not exclusively responsible for the cytotoxic effect of this toxin [24]. It has been demonstrated that ricin can induce apoptosis, cell membrane damage, membrane structure and function alteration, and release of cytokine inflammatory mediators [25-30]. In general, the inhibition of protein synthesis seems to precede apoptosis and be necessary for this event. It was, however, suggested that two different motifs present in ricin A-chain may be involved in ricin-mediated inhibition of protein synthesis and apoptosis [31,32] and that B-chain in human myeloid leukemia cells (U937) is able to induce apoptosis through its lectin activity without the contribution of the A-chain [33].

Elucidation of the entire mechanisms of ricin toxicity is crucial to fully utilize, but also to control all properties of this toxin. Ricin is being considered as one of the most toxic substances that exists. It can be used as a potential tool in bioterrorist attacks $[34,35]$. Thus, the development of effectively working antitoxin agents is of particular interest [36-39]. On the other hand, ricin conjugated with specific antibodies, other proteins, peptides or nanoparticles can be selectively directed to target cells. This ensures the possibility of a huge application of this toxin in medicine [40-44]. In this review, we describe the most important steps of ricin intracellular transport as well as diverse and complicated mechanisms of its action on cells. We also summarize the newest reports concerning the development of vaccines against ricin and biomedical applications of this toxin. 
A

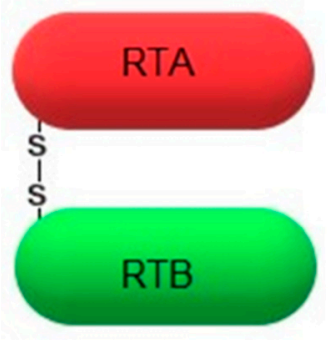

B

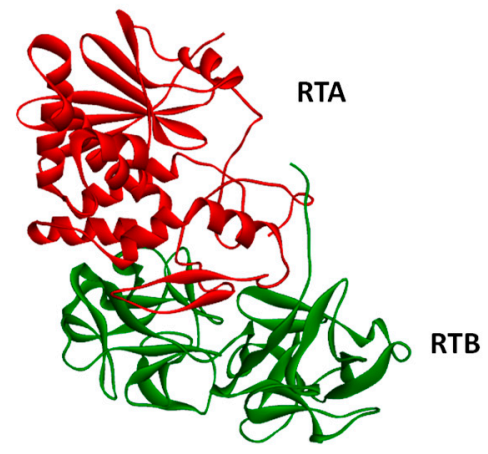

Figure 1. Schematic representation (A) and crystal structure (B) of the toxin ricin. The enzymatically-active subunit (A-chain) is marked in red, whereas the binding domain (B-chain) is presented in green. Both subunits are linked by a single disulfide bond. Crystal structure has been obtained from the PDB protein data bank (code 2AA1).

\section{Intracellular Transport of Ricin}

\subsection{Uptake of Ricin into the Cell}

Ricin B-chain recognizes complex types of carbohydrate receptors present on the surface of eukaryotic cells. These receptors contain either terminal $\mathrm{N}$-acetylgalactosamine or $\beta$-1,4-linked galactose residues [9]. Galactosyl-residues are abundant on the surface of most cell types, thus the majority of eukaryotic cells are sensitive to ricin. Moreover, this toxin can also bind the mannose-type glycans on cells that carry those receptors i.e., macrophages or rat liver endothelial cells [45]. This is due to the fact that both the A- and B-chains of ricin are glycoproteins that contain mannose-rich oligosaccharides. However, in contrast to galactosyl-residues, most cell types do not express mannose receptors and consequently ricin in such cells can be internalized exclusively by galactosyl moieties. It is assumed that $10^{6}-10^{8}$ ricin molecules can be bound to the cell surface [46]. Human cervical cancer cells (HeLa) for example contain $3 \times 10^{7}$ ricin-binding sites per cell [47], although not all of these sites are involved in toxin uptake.

After binding of ricin to the cell-surface receptors, the holotoxin is transported into the cell by endocytosis. It has been demonstrated that ricin is able to employ different endocytic mechanisms, which are believed to be mainly connected with the fact that it can recognize and bind to a great variety of cell surface components. It is even suggested that ricin can utilize all types of endocytic mechanisms that operate in a given cell [48]. First studies of ricin uptake demonstrated that it can be internalized by clathrin-dependent endocytosis in Vero cells (African green monkey kidney cells) [49]. However, further experiments showed that the inhibition of clathrin-coated pits formation in Hep-2 cells (derivative of HeLa) did not change ricin cytotoxicity [50] and that generally it can be taken into cells from non-coated parts of the cell surface membrane [51]. Additional evidence that ricin can be endocytosed by clathrin-independent mechanisms comes from experiments in which a dominant negative mutant of dynamin, a protein that is required for clathrin-related endocytosis, was used. The overexpression of the dynamin defective in GTP binding and hydrolysis in COS-7y cells (derived from kidney tissue of the African green monkey) did not alter cell sensitivity to ricin [52,53]. However, it should be noted that the expression of the same mutant dynamin (K44A) in HeLa cells inhibited ricin toxicity (see below). Moreover, it has been demonstrated that cholesterol plays an important role in endocytosis by clathrin-coated pits [54]. However, endocytosis of ricin was not changed significantly after cholesterol extraction from the membrane [54]. Effective extraction of cholesterol also disrupts other structures called caveolae that can be involved in clathrin-independent endocytosis [54,55], but independent experiments showed that caveolae were not necessary for ricin endocytosis [52]. Importantly, cholesterol is required for other endocytic mechanisms as well [56]. Thus, endocytic uptake of ricin can be both clathrin- and caveolae-independent [57]. Binding and endocytosis of 
ricin can be related to specific features of this toxin. Mutation that changes the secondary structure of its A-chain into a more helical structure (Figure 2A) has no influence on binding or endocytosis of modified holotoxin [58]. However, mutations that modify hydrophobicity of RTA (Figure 2B,C) significantly affect the binding of the altered holotoxins to the cell membrane [59]. A GFP-based reporter assay has very recently been applied in order to identify cellular components required for RTA intracellular transport in yeast [60]. The data indicated that proteins Syn8p, Sso1p and Snc1p influence ricin A-chain trafficking [60] (Figure 3). Syn8p and Snc1p form a complex that plays a role in protein uptake from the plasma membrane to endosomes [61]. Sso1p is a plasma membrane t-SNARE protein that together with v-SNARE Snc2p are required for the fusion of Golgi-derived vesicles with the plasma membrane [62]. It is unknown whether mammalian homologues of these proteins are also involved in ricin endocytosis.
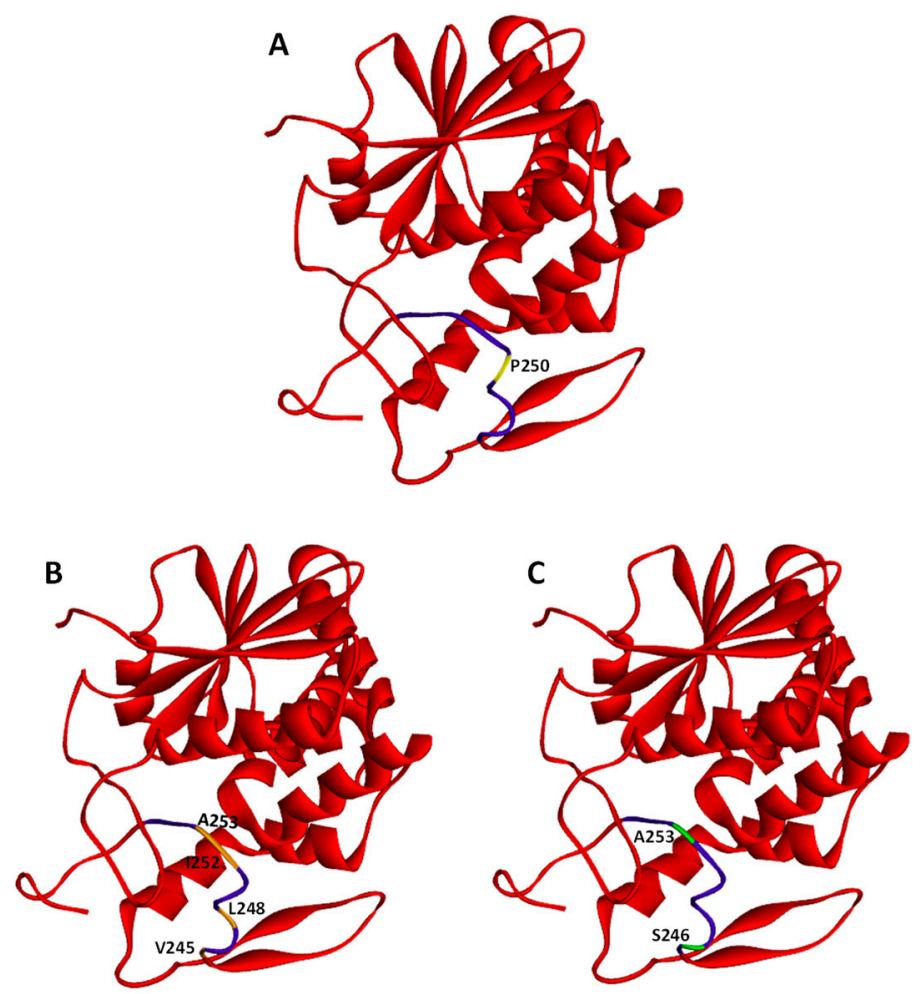

Figure 2. Crystal structures of ricin A-chain. PDB protein data bank (code 2AA1). Whole ricin A-chain (RTA) structures are marked in red. The hydrophobic region (Val245 to Val256) is indicated in purple. Several residues have been selected within the hydrophobic region and modified to obtain RTA with changed secondary structure or changed hydrophobicity. These residues are: (A) P250 (marked in yellow) has been modified (P250A) to produce RTA with a changed secondary structure; (B) V245, L248, I252, and A253 (marked in orange) have been modified (V245S, L248N, I252N, A253S) to obtain RTA with decreased hydrophobicity (RTA DHF); (C) S246 and A253 (marked in green) have been changed (S246V, A253V) to obtain RTA with increased hydrophobicity (RTA IHF). 


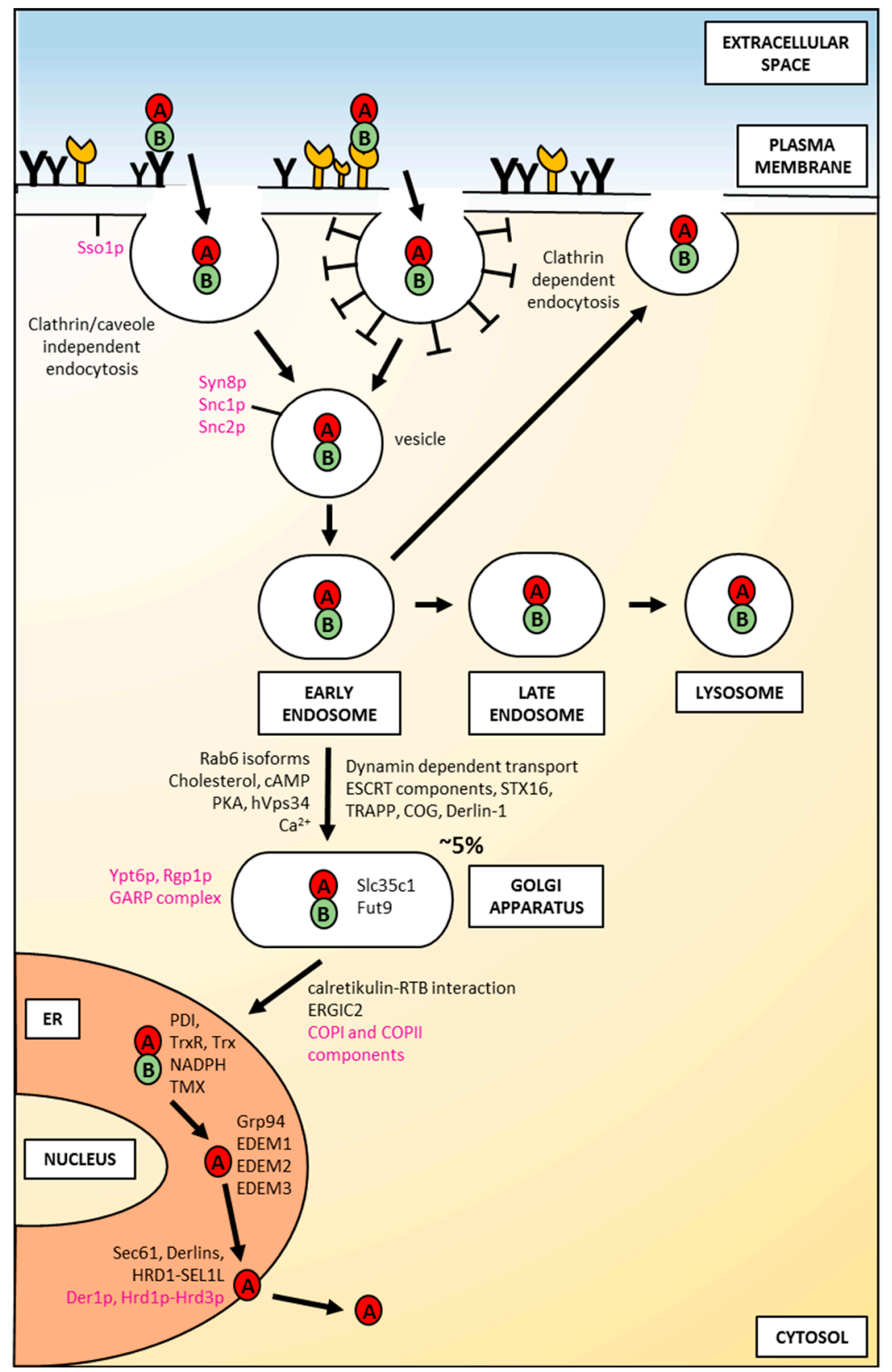

Figure 3. An overview of factors involved in the intracellular transport of ricin in mammalian and yeast cells. Yeast proteins are shown in magenta; mammalian proteins are shown in black. For a detailed description, please see the text.

\subsection{Intracellular Routing of Ricin to the Endoplasmic Reticulum}

After endocytosis ricin traffics to early endosomes (Figure 3). It has been demonstrated, that at this stage, the majority of toxin can be transported back to the cell surface in an apparently intact form [63]. In early endosomes, ricin also starts to be degraded [64]. This proteolysis is continued after its predominant transport to late endosomes and lysosomes [65] (Figure 3). Interestingly, efficient transport to lysosomes depends on how ricin is internalized. Significantly more toxin was transferred from endosomes to lysosomes upon internalization by mannose receptors in comparison to uptake by galactosyl-residues [45]. It was suggested that the different stabilities of ricin at endosomal low $\mathrm{pH}$ may be characteristic for these two binding mechanisms. This would explain the observed differences in the transport from endosomes to lysosomes between the two internalization pathways. In addition, as already mentioned in this review, modified ricin with a changed secondary structure 
that carries a point mutation in the hydrophobic region of the C-terminal A-chain (P250A) (Figure 2A) is more extensively degraded in endosomes/lysosomes than the wild-type toxin [57]. Both cathepsin $\mathrm{B}$ and cathepsin D were found to be involved in increased P250A ricin degradation. It cannot be excluded that P250 holotoxin has a somehow altered conformation in comparison to the wild-type toxin. This altered conformation might influence its endosomal/lysosomal degradation. It was visualized by electron microscopy that only about $5 \%$ of endocytosed ricin is transported to the trans-Golgi network (TGN) $[66,67]$. This transport proceeds directly from early endosomes, excluding the late endosomes-trans-Golgi pathway (Figure 3) [68]. From the Golgi complex, ricin is moved to the endoplasmic reticulum (ER). Ricin transport to the Golgi network and to the ER were confirmed experimentally $[66,67,69]$. Both pathways, endosome to Golgi and retrograde movement from the Golgi to the ER can engage complicated mechanisms of ricin intracellular transport. Brefeldin A is an important drug in these studies, because it disturbs the Golgi complex [70]. In cells treated with this compound, ricin transport was completely inhibited, and cell intoxication was blocked [71,72]. Interestingly, this was observed only in cells where the Golgi complex was sensitive to brefeldin A (BFA) [72].

In cells resistant to BFA, the polarized kidney epithelial cell line MDCK, BFA sensitized cells to ricin [73]. This drug does not change Golgi morphology in these cells and thus, it would be possible that increased transport to the Golgi apparatus is responsible for higher toxicity of ricin in MDCK cells. However, this did not seem to be the case. Moreover, it was demonstrated that BFA affects endosomal structures in those cells [73].

Ricin transport to the Golgi was also demonstrated by adding a short amino acid stretch, a tyrosine sulfation site that comes from rat cholecystokinin precursor. This extra stretch was added to the C-terminal end of the RTA, creating the ricin-A-sulf-1 [69]. When such a modified toxin was delivered to the Golgi complex, sulfotransferases that are specific enzymes for this compartment [74], catalyse the addition of sulfate to ricin. In cells that are preincubated with radioactive sulfate $\left(\mathrm{Na}_{2}{ }^{35} \mathrm{SO}_{4}\right)$, ricin becomes labelled, indicating transport of this toxin to the Golgi apparatus. Although, dynamin is not required for ricin endocytosis [52,53], at least, it seems that transport from endosomes to the Golgi network is dynamin-dependent (Figure 3) in HeLa cells [75]. It was demonstrated that overexpression of mutant dynamin in HeLa cells did not affect ricin degradation but transport of endocytosed ricin to the Golgi and total ricin toxicity were strongly inhibited [75]. Since ricin transport after endocytosis is based on vesicles, it can be predicted that intracellular traffic of this toxin would depend on some Rab proteins, GTPases that regulate many steps of vesicular transport [76]. Moreover, knowledge about the involvement or lack of association of particular Rabs in ricin transport defines, at least partially, specific mechanisms of its intracellular routing. It seems to be the case for the Rab9-dependent pathway, that delivers proteins from late endosomes to the TGN $[77,78]$. Overexpression of a dominant-negative mutant of Rab9, (Rab9S21N), failed to protect cells from ricin intoxication and did not prevent sulfation of modified ricin-A-sulf-1 [79]. In addition, ricin transport to the TGN is independent of Rab-11, clathrin [79], as well as Rab7 [48]. Rab-9-independent transport of ricin supports the notion that this toxin may be transported to the Golgi complex directly from early endosomes. It has been demonstrated that isoforms of Rab6, Rab6A and Rab6A' are important in early endosomes-TGN transport, with a special role of Rab6 $\mathrm{A}^{\prime}$ in this pathway [80] (Figure 3). Both isoforms are expressed at similar levels in all cells. They differ in three amino acids located near one of their GTP-binding domains [81]. It was demonstrated that the ricin-related Shiga toxin B-chain utilizes direct transport from early endosomes being dependent on Rab6A' [82]. The hypothesis that ricin may use a similar, early endosomes-TGN pathway was confirmed by experiments demonstrating that its transport to the TNG is regulated by Rab6A and Rab6A' [83]. Moreover, ricin transport between endosomes and the Golgi network is regulated by changes in the cholesterol level. Ricin can be endocytosed by cells depleted of cholesterol [54], but transport to the TGN was strongly inhibited when the cholesterol was reduced [84]. Interestingly, ricin delivery to the Golgi complex is also calcium-dependent [85] (Figure 3). Calcium regulates many steps in intracellular trafficking, including intra Golgi transport [86]. It was 
observed that in cells treated with thapsigargin, which specifically inhibits the ER $\mathrm{Ca}^{2+}$-ATPase, ricin transport to the Golgi was increased [85]. Moreover, genome-wide RNAi screens revealed human endosome-related genes such as the ESCRT component VPS2 (CHMP2A), Rab11FIP, and Rab5c as important for ricin toxicity [84]. Ricin transport also depends on the GARP complex, the SNARE Syntaxin16 (STX16), and the Golgi-related complexes TRAPP and COG [84] (Figure 3). However, VPS35, a central component of the Retromer that is required for the formation of transport carriers at the endosomes, is dispensable for ricin endosome-TGN transport. Mentioned already above, Rab6A and Rab6 $\mathrm{A}^{\prime}$ are human homologues of yeast Ypt6p [87]. Fluorescence-based reporter assay demonstrated that Ypt6p and its regulator Rgp1p are involved in RTA transport in yeast. Moreover, some GARP complex components (Vps51p and Vps54p) and Sft2p that enables fusion of endosome-derived vesicles with the Golgi are required for ricin traffic into cells [59]. Interestingly, Tlg2p (STX16 is a mammalian homologue of this protein) is not important for endosome-to-Golgi transport of RTA. In addition to the results described above, another simple reporter method based on the detection of changes in fluorescence emissions has been described and recently demonstrated to be useful for the identification of host cell proteins involved in intracellular RTA transport [88]. Endosome-to-Golgi transport of ricin is also regulated by cAMP signal transduction in the cell. It has been demonstrated that transport of ricin from endosomes to the Golgi network and further to the ER is controlled by the Golgi-associated regulatory subunit of protein kinase A (PKA) type II alpha isozyme in lymphocytes [89] (Figure 3). Moreover, transport of ricin to the Golgi is facilitated in human cells by hVps34 [90] (Figure 3), the only identified kinase that phosphorylates phosphatidylinositol (PI) in position 3 to produce PI(3)P. PI(3)P is needed for the vesicular localization of sorting nexins SNX2 and SNX4. All these events are required for ricin transport from endosomes to the Golgi complex [90].

Ricin transport to the Golgi complex can be observed by electron or immunofluorescence microscopy, whereas delivery of this toxin to the ER has never been directly visualized [91]. However, it was possible to use a genetically changed RTA containing two modifications: C-terminal Golgi-specific site for tyrosine sulfation (described above: RTA-sulf1) and three partly overlapping N-glycosylation sites (ricin-A-sulf-2) that flag an ER asparagine modification with carbohydrates [69]. It appeared that ricin-A-sulf-2 became sulfated in the TGN but also core glycosylated, indicating retrograde transport to the ER. Ricin itself does not contain an ER-targeting signal or KDEL retention sequence that would allow its interaction with KDEL receptors of the target cell and mediate toxin transport from the Golgi to the ER via coatomer protein I (COPI)-coated vesicles. However, RTB binds to resident luminal ER protein, calreticulin, a KDEL-tagged protein which indirectly allows for toxin transport to the ER [92]. Thus, calreticulin can operate as a retrograde transporter for ricin movement from the Golgi to the ER (Figure 3). However, calreticulin-deficient cells remained sensitive to this toxin, indicating that transport based on calreticulin-RTB interactions does not seem to be the main pathway for ricin traffic to the ER [92]. It was suggested that since ricin can bind glycolipids, some fraction of ricin may utilize lipid-sorting signals [93]. The second Golgi-to-ER transport pathway that was considered to be used by ricin is COPI-independent but Rab6-dependent [94]. However, it was demonstrated that the expression of the GDP-restricted mutant of Rab6A (Rab6A-T27N) did not alter ricin toxicity, suggesting that ricin is transported to the ER by a pathway that does not involve Rab6A [93]. Moreover, ricin was still toxic to cells when Rab6A and COPI were simultaneously inhibited. Thus, it was concluded that ricin can circumvent the Golgi apparatus. This hypothesis was confirmed in experiments in which the COPI protein complex was depleted of its subunit, epsilon-COP [94]. Cells were transfected with a modified $\varepsilon$-COP bearing a temperature-sensitive mutation. At the nonpermissive temperature, this protein become degraded, and the Golgi apparatus is changed morphologically. In such conditions, ricin could still be transported to the ER, even in the presence of brefeldin A which inhibits the binding of COPI to membranes and causes disassembly of the Golgi [95]. These results strongly suggest that ricin can bypass the Golgi stack on its way to the ER. However, it should be noted that such a pathway may be induced in the cells due to the changes enforced on these cells. Going back to the considerations about the classical Golgi-to-ER transport, it has been demonstrated by genome-wide screen that the ER-Golgi 
intermediate compartment protein 2 (ERGIC2) may be an important regulator of ricin transport to the ER [87]. siRNA-mediated downregulation of ERGIC2 protects cells against high doses of ricin. Consistent with these results, yeast homologue of ERGIC2 (Erv41p) and its complex partner Erv46p (mammalian ERGIC3) participates in RTA transport to the ER [59]. Both Erv46p and Erv41p are components of COPII vesicles, they form an active complex that traffics between the ER and the Golgi, being important for membrane fusion in ER/Golgi transport [96]. Additionally, the yeast reporter assay identified regulators of the ADP ribosylation factor (Arf) GTPases, Glo3p and Gea1p in ricin traffic in the cell. Arf initiates the budding of COPI-coated vesicles [97]. Two components of COPI, Sec22p and Rer1p are also important for ricin transport to the ER [96]. Rer1p is located at the Golgi membrane and operates as a retrieval receptor sending membrane proteins back to the ER [98]. Sec22p is a t-SNARE protein [99] that continuously traffics between the Golgi and the ER being involved in both anterograde and retrograde transport. Interestingly, it has been demonstrated that the mammalian homologue of Sec22p, Sec22B, is also important for ricin toxicity [87]. Thus, the components of both COPI and COPII seem to be important for ricin transport to the ER in yeast (Figure 3). Moreover, it has been suggested that COPII- and COPI-dependent ricin cycling between the ER and the Golgi is necessary for ricin dislocation to the cytosol and subsequent cytotoxicity [53]. It has been demonstrated very recently that GDP-fucose transporter residing in the Golgi, Slc35c1, and Fut9, a Golgi $\alpha 1,3$-fucosyltransferase, are both involved in fucosylation and are crucial for ricin toxicity [100] (Figure 3).

It should be noted that ricin A-chain can be directly delivered to the lumen of the ER by expressing a recombinant RTA version with an N-terminal signal peptide. The signal sequence is removed during RTA entry to the ER. Such an experimental approach appeared to be useful in yeasts [101,102], mammalian cells $[103,104]$ and plants [105]. This procedure enables analyzing the events that happen after entry of the toxin into the ER, studying RTA interactions with ER-specific proteins, toxin transport from the ER to the cytosol and mechanisms of its intoxication. Directed transport to the ER is useful in yeast since yeast are deprived of galactosylated cell surface receptors [106] that are able to bind to the ricin B-chain. Thus, externally added ricin does not intoxicate yeast cells. Moreover, in mammalian cells, RTB was directed to the ER to study the formation of the disulfide bond between A- and B-chains in the ER [103]. In plants, preproricin is initially synthesized. It is composed of a single polypeptide chain of the RTA and RTB [107]. The first 35 amino acid residues of preproricin contain a 26 residue $\mathrm{N}$-terminal signal sequence and a 9 residue propeptide [17]. The $\mathrm{N}$-terminal signal sequence directs the transport of the nascent polypeptide across the ER membrane into the ER lumen; the 9 residue propeptide is removed after proricin transport to the vacuole [17]. Using the mature RTA (with 35 amino acid residues of preproricin) in tobacco leaf cells, it was demonstrated that a significant fraction of the newly synthesized ricin is retrotranslocated from the ER to the cytosol for degradation [105].

\subsection{Ricin Translocation to the Cytosol}

It is strongly believed that only active A-chain of ricin is translocated to the cytosol [53,69,104,108-110]; however, some suggestions that the whole holotoxin can be transported out of the ER have also appeared [111]. Anyway, it has been demonstrated that RTA transport to the cytosol is proceeded by reduction of the internal disulfide bond that connects the ricin A- and B-chains [103]. This reduction is catalyzed by the protein disulfide isomerase (PDI) [112], the main ER foldase that is responsible for the formation, cleavage and isomerisation of disulfide bridges [113]. It has been demonstrated that PDI interacts with the ricin B-chain and can both reduce and form the disulfide bond between ricin subunits [103]. However, it seems that the disulfide reductase activity of PDI needs to be enhanced by thioredoxin reductase (TrxR) [114] (Figure 3). In eukaryotes, two thiol-disulfide exchange systems exist: The thioredoxin system that contains thioredoxin and thioredoxin reductase [115] and the glutaredoxin system that includes glutaredoxin and glutathione reductase [116]. They catalyze fast and reversible reactions between cysteines in their active site and cysteines of their disulfide substrates using NADPH and reduced glutathione (GSH) as a source of reducing equivalents, respectively. In the case of ricin, it was demonstrated that PDI, TrxR and thioredoxin (Trx) used separately were unable 
to directly reduce ricin holotoxin [114]. However, PDI and Trx in the presence of TrxR and NADPH could release RTA from ricin holotoxin in vitro. PDI functioned only after pre-incubation with TrxR. The reductive activation of ricin was more efficient in the presence of glutathione [114]. Disulfide bond reduction in ricin holotoxin enables liberation of RTA, but it is also suggested that it serves to activate the catalytic activity of ricin A-chain [117]. It was demonstrated that recombinant proricin activity was dependent on its release from the mature ricin that was generated from proricin. Moreover, it was shown that another member of the PDI family, TMX, a transmembrane thioredoxin-related protein, reduces disulfide bridges in ricin holotoxin [118]. TMX can activate RTA by promoting interactions between ricin A-chain and ER proteins that facilitate transport of RTA to the cytosol prior to subsequent cell intoxication [118]. Increased ability of ricin to intoxicate cells after reductive release of RTA from holotoxin may result, at least partially, from the fact that liberated ricin A-chain can be unfolded to a certain extent in the ER. Such unfolding is probably required for RTA retrotranslocation to the cytosol through a relatively narrow ER channel. In support of this hypothesis, it was demonstrated that the introduction of an intrachain disulfide bond into the ricin A-chain significantly decreased the cytotoxicity of modified toxin [119]. This was explained by a constraint in the unfolding of RTA. Moreover, it was observed that a native A-chain is quite unstable at pH 7.0 [120]. Partially-unfolded RTA was sensitive to protease digestion and disrupted tertiary structure [120]. Thus, it was considered that ricin A-chain should be unfolded in the lumen of the ER, where it is recognized by several ER chaperones in a way similar to misfolded proteins.

Proteins that fail to become properly folded are recognized by specific ER factors that promote their transport to the cytosol for proteasomal degradation (for review see for example Refs. [121-124]). This process is called ER-associated degradation (ERAD) [122,125]. It is believed that the ricin A-chain, similarly to other A subunits of particular toxins, utilizes ERAD in its transport from the ER to the cytosol (for review see for example Ref. [110]). However, the main difference between RTA and typical ERAD substrates is that ricin A-chain avoids effective degradation by proteasome, being instead activated in the cytosol to exert its cytotoxic effect. Still, little is known about specific ERAD factors that facilitate RTA transport out of the ER. It has been demonstrated that both the A- and B-chain of ricin interact with one of the main Hsp70 chaperone family proteins, Bip (Grp78) [126]. Despite these interactions, overproduction of BiP significantly decreased RTA transport out of the ER and protected cells against this toxin. It cannot be excluded that ricin interacts with BiP that is already engaged in a bigger protein complex that forms in the ER and inhibits ricin transport to the cytosol. It has been demonstrated very recently that BiP can form a direct complex with Grp94 (Hsp90 chaperone protein) in the absence of a substrate [127]. Moreover, this interaction is nucleotide-specific. BiP and Grp94 more efficiently interact with each other at high ADP concentrations and possess lower affinity to interaction at high ATP concentrations. It has been demonstrated that inactivation of Grp94 by a specific inhibitor protects cells against ricin [128]. Except for classical chaperones (Hsps: 40, 70, 90 and 100), the ER possesses a unique class of carbohydrate-dependent lectins that recognize different ERAD substrates both in a glycan-dependent and independent manner [122,123,129]. The most known members of these lectin chaperones are calnexin/calreticulin [122,130] and the EDEM family [131-134]. Ricin B-chain interaction with calreticulin facilitates Golgi-ER transport (see above Ref. [92]), but it is not proven that this chaperone is directly involved in ricin transport to the cytosol. This is opposite to the role of EDEM1, EDEM2 and EDEM3. It has been demonstrated that RTA interacts with all EDEMs [135-138] (Figure 3). However, the mechanisms of their action during ricin translocation out of the ER are not the same. EDEM1 probably has a higher affinity for typical misfolded proteins than for ricin [135]. Thus, it can promote its transport to the cytosol only when ER translocons are not intensively occupied by ERAD substrates. EDEM2 directly facilities ricin transport to the cytosol, which induces higher cell sensitivity to this toxin [136]; whereas overproduction of EDEM3 is not relevant for RTA translocation to the cytosol [138]. Interestingly, ricin A-chain interaction with EDEM1 and EDEM2 and consequently its translocation to the cytosol and overall cytotoxicity is related to the appropriate structure and degree of hydrophobicity of RTA $[57,58]$. RTA P250A (with substitution of proline to 
alanine at amino acid position 250) of the highly hydrophobic C-terminal region (Val245 to Val256) has a changed secondary structure to a more helical one without alternations in RTA hydrophobicity [57] (Figure 2A). On the other hand, the substitutions V245S, L248N, I252N, A253S, S246V, and A253V in this region produce RTA with decreased (RTA DHF) (Figure 2B) and increased hydrophobicity (RTA IHF) (Figure 2C), respectively [58]. Both RTA P250A and RTA DHF show significant reduction in their ability for interactions with EDEM1 and EDEM2 [57,58]. Additionally, transport of RTA P250A to the cytosol and toxicity of this modified ricin were not dependent on EDEM1 and EDEM2 overproduction. These results demonstrate that for interactions between EDEM1, EDEM2 and RTA, appropriate structure and hydrophobicity of the substrate are important. RTA with a decreased amount of $\beta$-sheet structures that directly resulted from increased $\alpha$-helicality [57] and RTA with very low hydrophobicity of the C-terminal region [58] exhibit reduced interactions with EDEM chaperone proteins. Interestingly, it was demonstrated that a conformational change of RTA is crucial for its binding to the surface of the ER membrane. At the physiologically relevant temperature of $37^{\circ} \mathrm{C}$, RTA loses some of its helical content and rearranges the conformational structure in such a way that it exposes its C-terminal region to the membrane interior [139]. Such an insertion into the ER membrane might be necessary for RTA translocation to the cytosol. It can be concluded from these observations that an additional limiting step in RTA P250A retrotranslocation to the cytosol (apart from lack of EDEM1 and EDEM2 assistance) might result from its inability to be subjected to additional conformational changes allowing it to be stably inserted into the ER membrane. As already mentioned, EDEM proteins can recognize glycan residues present on their substrates but can also bind other structures, e.g., hydrophobic regions or unfolded motifs. This second option seems to be important for EDEMs-ricin interactions since recombinant ricin expressed in E. coli that was used in the experiments, lacks oligosaccharides that are normally added to ricin A-chain derived from plants [140]. On the other hand, it was demonstrated in S. cerevisiae that RTA glycosylation (that occurs on asparagines 10 and 236) promotes its transport from the ER to the cytosol and increases ricin cytotoxicity as block in RTA glycosylation impairs depurination of specific adenine in 28S rRNA [141]. Moreover, in the case of ricin, a glycan signal can stabilize this toxin [142]. This is opposite to typical misfolded proteins where specific oligosaccharide recognition becomes a signal for their degradation. Ricin stabilization was demonstrated by using GFP-tagged RTA containing a point mutation (E177Q) which attenuates its cytotoxicity (GFP-RTA E177Q). This toxin, engineered with a murine signal sequence for direct co-translational delivery into the ER of the host cell, was destabilized by inactivating genes required to generate and recognize the N-glycan residues [142].

In its transport from the ER to the cytosol, ricin A-chain definitely utilizes one specific type or different classes of the ER membrane translocation channels (Figure 3). Three main types of ER translocons have been identified so far: the Sec61 complex [143-147], the Derlin proteins [148-153] and several ER membrane multi-spanning ubiquitin ligases, including HRD1 (Hrd1p in yeast) [154-159]. The main function of the ubiquitin ligases is connected with polyubiquitination of polypeptides emerging in the cytosol prior to their transfer for the proteasomal degradation (for review see for example Ref. [160]). However, the ubiquitin ligases can also form a translocation channel being directly involved in ERAD substrates' transport to the cytosol [156,157]. The role of Sec61 and Derlin proteins in RTA transport out of the ER is not clear and unambiguous. It is still discussed whether these channels can be used by ricin A-chain as real translocons. It has been demonstrated that RTA can interact with Sec61 $\alpha$, the main component of the Sec61 complex in mammalian cells. This was shown by co-immunoprecipitation studies [108,135] and additionally demonstrated with isolated yeast ER-derived microsomes [101]. Moreover, the rate of RTA degradation was significantly decreased in yeast mutants defective in protein export via the Sec61p translocon [101]. On the other hand, genome-wide RNAi screens did not identify Sec61 as important in ricin toxicity [87]. In these experiments, Sec61 was effectively downregulated, as a mix of the single most potent siRNA against each gene of the Sec61 complex was used. In addition, gene silencing of Sec61 $\alpha$ did not influence RTA transport from the ER to the cytosol in HEK293 (human embryonic kidney) cells [161]. 
However, it cannot be excluded that unchanged ricin A-chain translocation to the cytosol upon Sec61 $\alpha$ downregulation might result from the existence of undefined compensatory mechanisms that direct ricin to other ER channels. In the case of Derlins, the majority of collected data indicate that these proteins are not crucial for RTA transport to the cytosol. The rate of RTA degradation was not decreased in yeast cells devoid of Der1p (mammalian Derlin-1) [101]. Cells stably transfected with dominant negative constructs of Derlin-1 and Derlin-2 treated with extrinsically added ricin [135], as well as dominant negative Derlin-1 transfected mammalian cells expressing an ER-localized RTA construct [104], did not exhibit altered ricin A-chain transport to the cytosol when compared to the control cells. Moreover, overproduction of Derlin-1 or Derlin-2 did not influence RTA dislocation to the cytosol [162]. In contrast, single Derlin protein downregulation as well as gene silencing of all three Derlins (Derlin-1, Derlin-2 and Derlin-3) showed significant rescue against ricin intoxication [87]. The assumption that Derlins can play a specific role in ricin transport across the ER membrane was strengthened by an observation showing that two factors, UFD1L and NPLOC4, that bind to Derlins, are required for ricin intoxication [87]. However, considering the effect of Derlin-1 on overall ricin cytotoxicity, it should be noted that the ER-cytosol step is not the only one that contributes to this process, since it was demonstrated that Derlin-1 is necessary for an efficient retrograde transport of ricin from endosomes to the Golgi apparatus [163] (Figure 3). The role of HRD1 ubiquitin ligase and its cofactor SEL1L seems to be the most obvious in RTA translocation to the cytosol (Figure 3). It was shown that SEL1L is required for ricin A-chain transport to the cytosol and SEL1L knockdown protects cells from ricin [104]. Similarly in yeast, Hrd1 and its cofactor Hrd3p facilitate RTA transport out of the ER [164]. However, recently published results demonstrated that Hrd1p and Derl2 (mammalian Derlin-2) contribute to, but do not exert, an absolute requirement for ricin intoxication [165].

\section{Cytotoxic Action of Ricin on Cells}

\subsection{Activation of Ricin A-Chain in the Cytosol Regulation of RTA Folding versus Degradation}

After translocation to the cytosol, ricin must refold into its biologically active conformation to modify its cytosolic targets (Figure 4). It is considered that there are three general pathways by which ricin A-chain can obtain its catalytic, folded structure: binding to cytosolic chaperones $[53,128,166]$, ribosome-mediated refolding [120], and interactions with ribosomal and proteasomal factors [166]. However, it should be noted that not all of the RTA molecules translocated to the cytosol can act as an active toxin. Ricin A-chain is partially degraded by the $26 \mathrm{~S}$ proteasome and this degradation can be blocked by specific proteasome inhibitors $[57,108,135,136,167]$. It seems that in mammalian cells, the majority of RTA escape proteasomal degradation $[108,135]$. However, in yeasts, it was shown by pulse-chase experiments that only $20 \%$ of translocated toxin appeared to be completely stable, whereas the rest was degraded during the first hour of the chase [101]. Cell fractionation has shown that this stable RTA was present in the cytosol. Interestingly, yeast proteasomes discriminate between native and structurally defective forms of RTA [164]; native RTA can avoid proteasomal degradation. This phenomenon is explained by the fact that ricin A-chain contains only two lysine residues which generally do not become efficiently ubiquitinated during toxin transport to the cytosol $[109,167,168]$. The lack of RTA lysine ubiqitination is common for both yeast and mammalian cells despite the fact that requirements for the ubiquitin-dependent system, Cdc48p/p97 that extracts ricin A-chain out of the ER membrane differ between these two groups. In yeast, RTA transport to the cytosol is independent of Cdc48 [164], whereas in mammalian cells, the expression of a dominant negative mutant of p97 blocked ricin toxicity and increased the time required for RTA transport to the cytosol [169]. The second general mechanism that allows toxins to avoid proteasomal degradation might be connected with their ability to obtain its fully-folded structure relatively quickly after transport to the cytosol. It has been demonstrated that folded proteins do not become proteasomal substrates even if they possess many lysine residues on their surface [170]. However, in the case of ricin, it was shown that it cannot refold spontaneously after thermal denaturation in vivo [120]. At $37^{\circ} \mathrm{C}$, ricin has a conformation similar to a 
molten globule, and it was impossible to obtain its native state by manipulation of the buffer conditions or by the addition of a stem-loop dodecaribonucleotide or deproteinized E. coli rRNA, both of which are substrates for ricin A-chain. Thus, RTA is considered to be a toxin with a slow refolding rate. This rate is much slower than for example the A subunit of the cholera toxin (CTA1) that displays lower detectable sensitivity to degradation by the proteasome when compared with ricin [171].

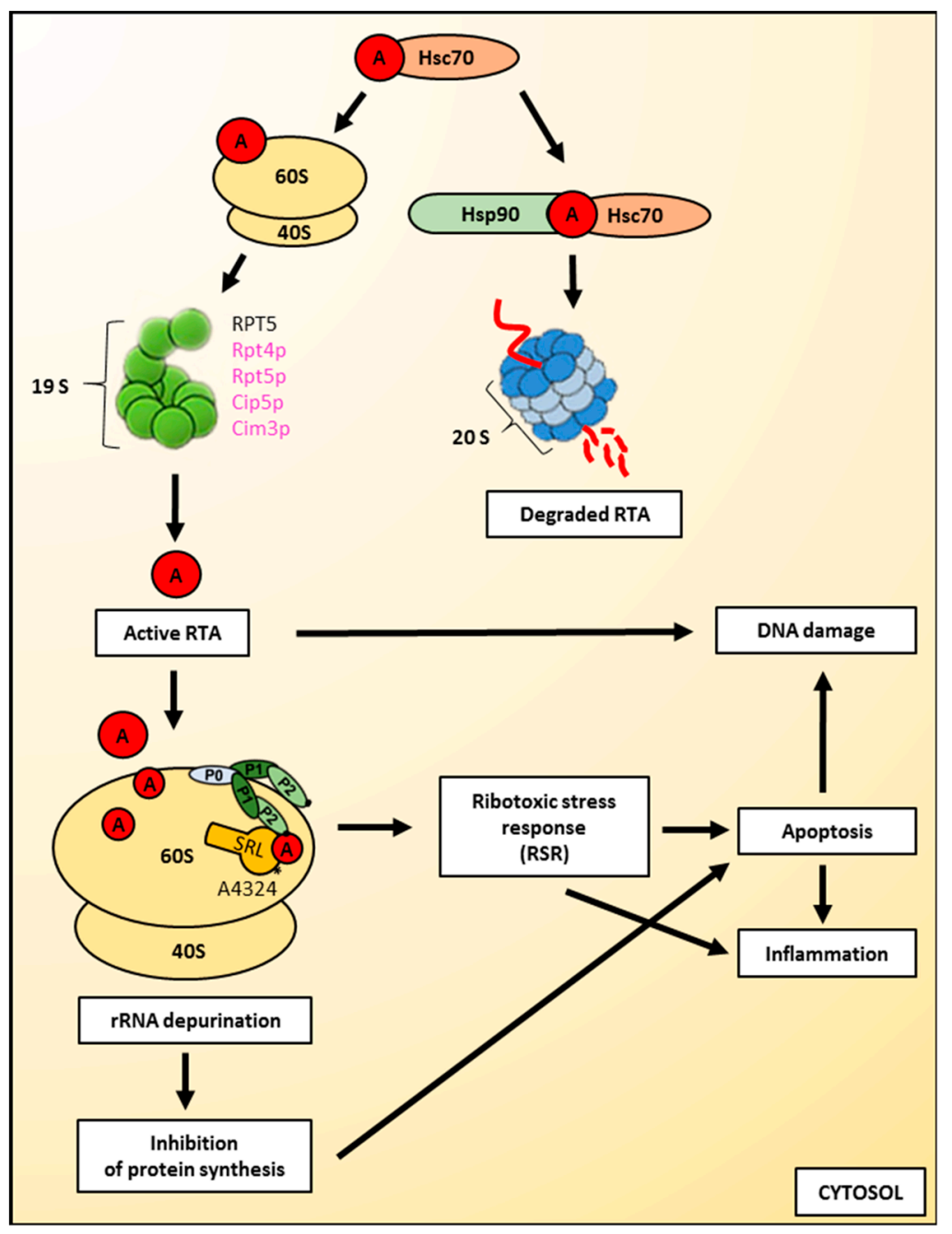

Figure 4. Cytotoxic action of ricin on cells. Binding to cytosolic chaperones, ribosome-mediated refolding and interactions with ribosomal and proteasomal factors are pathways by which ricin A-chain can obtain its active form. However, ricin A-chain is partially degraded by proteasomes. Active ricin A-chain is an $\mathrm{N}$-glycosidase that removes a universally-conserved adenine at position 4324 from the $\alpha$-sarcin-ricin loop (SRL) of the rRNA present in the large ribosomal subunit. The interaction of ricin A-chain with the large ribosomal subunit is facilitated by the ribosomal stalk structure, composed of P0, P1 and P2 proteins. The damage of the $28 \mathrm{~S}$ rRNA by ricin leads to the inhibition of protein synthesis and triggers the ribotoxic stress response (RSR). Both pathways can induce apoptosis and further inflammation. Ricin A-chain can also directly induce DNA damage. Yeast proteins are shown in magenta; mammalian proteins are shown in black. 20S refers to the core particle, whereas 19S refers to the regulatory particle of the proteasome. For a detailed description, please see the text.

The interactions of ricin A-chain with ribosomal proteins and cytosolic chaperones are crucial in gaining its proper conformation. These interactions also facilitate RTA transport to the cytosol. It has been demonstrated that an ATPase subunit of the 19S proteasome cap in yeast, Rpt4p [164], and two other proteins of the cap, Cim3p and Cip5p [101], are important for ricin A-chain transport from the ER. 
However, no obvious requirement for this transport was observed for the other Rpt subunits, Ubr1p or the proteasome core itself [164]. It should be noted that Rpt4p can cooperate with Cdc48p in the extraction of an endogenous substrate from the yeast ER [172]. Chaperone-like activity of ribosomes were demonstrated in experiments showing that partially-unfolded ricin A-chain was able to obtain full catalytic activity in the presence of salt-washed ribosomes [120]. The ATPase subunit RPT5 of the 19S proteasome cap prevents aggregation of denatured RTA and enhances the recovery of catalytic activity of ricin A-chain in vitro [166]. In addition, it was shown in vivo that Rpt5p is required for maximum toxicity of RTA dislocated from the yeast ER. Interestingly, the anti-aggregation properties of the $26 \mathrm{~S}$ proteasome are independent of its proteolytic activities [166]. Cytosolic chaperones protect and activate ricin A-chain but they also have a much broader spectrum of action, as they regulate the general fate of RTA dislocated from the ER [128]. The mechanisms of cytosolic chaperones activity include ricin A-chain binding to Hsc70 (cytosolic member of Hsp70 family). It was shown that Hsc70 prevents aggregation of the heat-inactivated toxin and can recover its catalytic activity. Inhibition of cytosolic Hsc70 protected HeLa cells from ricin [128]. However, the concentration of Hsc70 co-chaperones may regulate the amount of RTA that can gain the catalytic activity and the fraction that will be degraded. Interaction of the RTA-Hsc70 complex with BAG-2 and Hip induces RTA activity in vitro, promoting the sensitivity of cells to ricin. On the other hand, co-chaperones BAG1 and CHIP facilitate ricin A-chain destabilisation. CHIP is an E3 ubiquitin ligase that interacts not only with Hsp70 but also with another type of cytosolic chaperone, Hsp90. Moreover, another dual co-chaperone, Hop, is an Hsp70-Hsp90 organizing protein. It reversibly links Hsp70 and Hsp90 by recruiting Hsp90 to the existing Hsp70-substate protein complex. This promotes transfer of the substrate from Hsc70 (Hsp70) to Hsp90 [173]. Overexpression of Hop decreases sensitivity to ricin, suggesting that sequential interaction of RTA with Hsc70 and Hsp90 directs the toxin to inactivation and destabilisation [128]. Consistent with this hypothesis, inhibition of Hsp90 sensitized cells to ricin [128]. RTA inactivation may be mediated by an ubiquitination process. This mechanism is not fully elucidated, but it was suggested that a low amount of RTA can be ubiquitinated in the cytosol. In yeast, ubiquitination occurs via an unknown E3 ligase [164]. It has been demonstrated that RTA is not ubiquitinated by Hrd1p during dislocation [164], but introduction of additional lysyl content into RTA reduces its cytotoxicity by increasing ubiquitin-mediated proteasomal degradation [168]. In yeast, no significant changes in the growth rate were observed in cells lacking individual Hsp40, Hsp70 and Hsp90 family members or the Hsp70 and Hsp90 co-chaperones [164].

\subsection{Ricin A-Chain Action on Ribosomes}

Ricin A-chain is an $\mathrm{N}$-glycosidase that removes a universally-conserved adenine at position 4324 in mammalian cells (Figure 4) and A3027 in yeast from the $\alpha$-sarcin-ricin loop (SRL) of the rRNA present in the large ribosomal subunit $([5,8,10,11,174]$ and see Introduction for details). This disables the binding of specific elongation factors to the ribosome and inhibits protein synthesis $[9,16,17]$. It is known that ricin A-chain influences the structure of the ribosomal RNA. It alters the dynamic flexibility of the GTPase activating centre of the ribosome, which part is SRL. These conformational changes disturb the transition between the pre-and post-translocational states of the elongation cycle [175]. As earlier mentioned in this article, ricin does not depurinate E. coli ribosomes. However, its inability to exert a cytotoxic effect on prokaryotic ribosomes does not result from the fact that RTA is incapable to act on the 23S rRNA from the large bacterial ribosomal subunit. In fact, ricin A-chain depurinates the sarcin-ricin loop of naked 23S rRNA [176], suggesting that for the proper catalytic activity of ricin, the whole ribosome and particularly ribosomal proteins are crucial [177]. It has been demonstrated that the ribosomal stalk structure facilitates the interaction of ricin A-chain with the large ribosomal subunit in eukaryotes [177-179] (Figure 4). The human ribosomal stalk structure is composed of three types of phosphoproteins, P0, P1 and P2. They are assembled into a pentameric protein complex comprised of a single P0 protein bound by two heterodimers of P1 and P2 proteins $[180,181]$. It has been shown recently that P1-P2 proteins represent a primary binding site for RTA [182], with a more critical role for 
the P1B-P2A dimer [183]. Interestingly, the stalk structure differs significantly between prokaryotic and eukaryotic ribosomes. In prokaryotic cells, the stalk proteins exhibit very little sequence homology to eukaryotic counterparts. Thus, it was suggested that they are solely functionally analogous to eukaryotic proteins [184]. This important observation significantly contributes to our understanding of species specificity for ricin and ultimately defines the sensibility of the SRL for depurination by this toxin. The ribosomal stalk is a dynamic structure located in proximity to the SRL. It was suggested that ricin A-chain binding to the stalk proteins may allow RTA to be placed directly by the sarcin-ricin domain, which facilitates more efficient detection of the rRNA substrate by RTA [177]. Based on the analysis of interactions between RTA and the stalk proteins, a two-step binding model was proposed with the first step characterized by a slow association and dissociation rate, and a second step with much faster rates of interactions $[185,186]$. Within this model, the binding of RTA to the stalk was then more specifically divided into four phases. In the first phase of binding, ricin A-chain is concentrated on the surface of the ribosome and directed to the stalk $[185,186]$. This step is based on slow and nonspecific electrostatic interactions. In the next phase, RTA interacts with the stalk through more specific and stronger electrostatic interactions, which are saturable. Step three represents the delivery of RTA to the SRL $[185,186]$. This transfer is mediated by the C-terminal domain (CTD) of the stalk proteins. Their involvement in this process decreases the possibility of RTA dissociation out of the ribosome and leads to rapid recruitment of the toxin by SRL. Finally, in the fourth phase, ricin A-chain specifically depurinates the $\alpha$-sarcin-ricin loop $[185,186]$. Recently published results demonstrated that the C-terminal domain of P1 is the main docking site for RTA as deletion of P1 CDT but not P2 CDT decreased the affinity of the stalk structure for ricin A-chain [182]. However, studies of another group have demonstrated that RTA mainly recognizes the highly conserved C-terminal tail of P2 (residues 106-115) in which two residues, Leu and Phe, are critical for the interaction with RTA [187]. These residues might also be important for RTA binding to other P proteins. Moreover, the crystal structure of RTA with P2 protein shows that GFGLFD motif of the C-terminal P2 is inserted into a hydrophobic pocket of RTA, suggesting that the flexibility of the P2 peptide interaction with ricin A-chain is based on hydrophobic rather than electrostatic interactions [188]. It was shown before that seven arginine residues located at the RTA/RTB interface are involved in ricin A-chain interaction with the ribosome $[189,190]$. In the holotoxin structure, each arginine residue is covered by RTB, completely or only partially [191]. Nevertheless, this causes the ribosome binding site on RTA to be blocked by RTB, thereby disabling ricin holotoxin to depurinate ribosomal rRNA. Thus, holotoxin RTA can become catalytically active only after its release from RTB which results in revealing the ribosome binding site $[192,193]$. Interestingly, RTA with a modified ribosome binding site is less toxic than a variant with lower catalytic activity but unchanged ribosome binding activity [194]. It has been demonstrated that by introducing R189A/R234A and R193A/R235A double mutations, ricin A-chain binding to the stalk stimulates ribosome depurination by orienting the active site of RTA toward the SRL, thereby allowing docking of the target adenine into the active site [192]. Recently published results also showed that Arg235 of ricin A-chain serves as a main interacting residue with ribosomes and cooperates with nearby arginines to allow RTA to interact with the stalk with fast kinetics in order to achieve the binding specificity necessary for SRL depurination [191]. It was initially proposed, based on a study with analytical ultracentrifugation, that RTA interacts with the 60S ribosomal subunit with a molar stoichiometry of 1:1 [195]. However, a model involving conformational changes is currently preferred [196]. In this model, after binding of RTA to the ribosome, conformational rearrangements of both RTA and ribosomes occur, allowing the formation of a high affinity complex. These conformational changes directly influence the catalytic activity of ricin A-chain. It has recently been shown that the flexibility of the $\alpha$-helix (residues 99-106) of RTA is connected with the regulation of the depurination activity by ricin A-chain, which directly influences the rate of protein synthesis inhibition [197]. Moreover, it was proposed that the flexibility of the $\alpha$-helix could affect the side chain orientation of Glu-177, which is critical for the depurination activity of ricin $[198,199]$. Interestingly, ricin A-chain is not able to bind to the isolated $40 \mathrm{~S}$ ribosomal subunit, however, its rRNA and/or ribosomal proteins 
may promote optimal and stable interactions of ricin with the whole ribosome, since binding of RTA to $80 \mathrm{~S}$ ribosomes was approximately 3.5-fold stronger than binding to the isolated 60S subunits [177,195]. The interaction of ricin A-chain with the ribosomal stalk structure has been evaluated as a potential drug target [200]. Several peptides (3 to 11 amino acids in length) corresponding to the C-terminal end of P proteins were examined in their ability to interact with RTA and block its catalytic activity. It appeared that a four amino acid peptide is the shortest one that can inhibit depurination activity of RTA by preventing toxin binding to the ribosome [200].

It has been demonstrated that one molecule of ricin A-chain is able to inactivate over 1500 ribosomes per minute in a cell-free preparation of ribosomes $[18,19]$. The multiplexed digital droplet (ddPCR) assay showed that depurination events in lung cell cultures can be detected as early as $1 \mathrm{~h}$ after ricin treatment $(1 \mathrm{nM})$ and within $9 \mathrm{~h}$ of exposure the maximum ribosomal damage of $70 \%$ was reached [201]. This effect was sustained for at least $24 \mathrm{~h}$ post-exposure. However, it should be noted that depurination in cell-based systems would be expected to occur at a lower rate than in cell-free systems. In the cell, the whole A-B holotoxin is applied and there is a lag time that is required for toxin uptake and its intracellular transport until the rRNA substrate is reached. Depurination rates are difficult to compare between in vivo and in vitro experiments, moreover, the rates of depurination may differ between cell types $[176,201,202]$. Nevertheless, it can be assumed that ricin-induced depurination is a very rapid enzymatic process.

\subsection{Mechanisms of Ricin-Induced Apoptosis}

Despite the very effective ricin-mediated rRNA depurination event that results in the inhibition of protein synthesis, it cannot be stated that these processes by themselves lead to cell death [24,30-33,203]. It has been demonstrated that ricin can induce apoptosis, autophagy and release of cytokine inflammatory mediators [25-30,204] (Figure 4). These processes have been studied for over two decades with a growing number of results that indicate their significance for cell death observed. However, it is still unclear whether the inhibition of protein synthesis is sufficient to induce apoptosis in all cell lines and to what extent other factors are required for the induction of apoptosis [30,205].

Early reports describing that ricin is capable of inducing cell death by apoptosis came from in-vitro studies that correlated cellular morphological changes with apoptosis [26,206-208] and from in-vivo studies in which epithelial, endothelial and myeloid cells were used [204,209-211]. It was observed that cells treated with ricin exhibit chromatin condensation, membrane blebbing, rounding of the cells, formation of apoptotic-like bodies, and DNA fragmentation that are considered to be typical markers of apoptosis [26,27,206,207,209,210]. Moreover, it has been reported that intracellular targets of ricin are not limited only to the ribosomal RNA. Deproteinized (naked) RNA, synthetic oligoribonucleotides, nuclear and mitochondrial DNA, polyA, tRNA and viral nucleic acids were published to be depurinated by purified ricin and other type II RIPs [211]. These ricin activities were often classified as actions not directly connected with apoptosis. It has been reported that the early DNA damage observed in human endothelial cells HUVEC in parallel to the arrest of protein synthesis was not a consequence of ribosome inactivation or apoptosis but results from direct action of ricin on DNA [212] (Figure 4). Li and Pestka [213] suggested that ricin and other RIPs may induce rRNA damage, in addition to the classical way, also through increased expression and activation of host RNases. Moreover, ricin-mediated rRNA depurination might facilitate toxin interaction with one or both dsRNA-binding domains of a kinase associated with the ribosome, PKR (double-stranded RNA-activated protein kinase), thereby causing the activation of PKR [214]. PKR plays a role in interleukine-8 (IL-8) induction, which may trigger the ribotoxic stress response (RSR) (see below).

It is considered that the main mechanisms of ricin-dependent apoptosis are based on the activation of caspases [215-222], Bcl-2 family members [223-225], and stress-associated signaling pathways $[102,213,215,219,226-238]$. The mechanisms of ricin-induced cell death promoting pathways are also connected with direct and indirect action of ricin on DNA [212,239], ricin-mediated reactive oxygen species production [24,215,218,224,240-242], and ricin B-chain-induced apoptosis [33,243]. 


\subsubsection{Ricin-Induced Activation of Caspases}

It is assumed that apoptosis can be activated via two major pathways, extrinsic and intrinsic. The extrinsic or receptor-mediated mechanism includes ligation of the death receptors that stimulate the activation of the initiator caspase-8, which then triggers downstream events by direct stimulation of caspase- 3 or cleavage of the protein Bid. In the intrinsic pathway, mitochondria function as the main operation center. Damage to mitochondria results in outer membrane depolarization and permeabilization (MOMP) which triggers the release of several proapoptotic factors, including cytochrome c. This leads to the activation of caspase-9, which then triggers effector caspase-3 [244,245]. Poly (ADP-ribose) polymerase (PARP) is one of the best described substrates for caspase- 3 which can cleave 116kD PARP into 85 and $31 \mathrm{kD}$ fragments [246]. PARP cleavage is one of the most studied hallmarks of apoptosis. It is believed that mitochondria and the intrinsic pathway of apoptosis activation are critical in signaling for cell death in ricin-intoxicated cells. It has been reported that in ricin-treated cells, a loss in mitochondrial membrane potential, rapid release of cytochrome c, activation of caspase-9 and caspase-3, and DNA fragmentation were observed [215-222]. Caspases may be profoundly involved in the pathway, resulting in DNA fragmentation [220,247]. Moreover, ricin-dependent PARP cleavage has been observed in different cell lines including HeLa [218] and U937 cells [216,220]. Interestingly, studies performed in U937 cells might, at least partially, answer the question about correlation between different ricin-mediated death mechanisms in cells. In ricin-treated U937 cells, intracellular NAD $(+)$ and ATP levels were decreased and this reduction was followed by ricin-mediated protein synthesis inhibition [220]. The PARP inhibitor, 3-aminobenzamide (3-ABA), blocked the depletion in NAD $(+)$ and ATP levels. Significant PARP cleavage was observed more than 12 $\mathrm{h}$ after ricin addition, while DNA fragmentation reached a maximum level within $6 \mathrm{~h}$ of incubation [220]. Thus, it was concluded that the PARP cleavage is not an early apoptotic event associated with the induction of ricin-mediated apoptosis and that the pathway leading to cell lysis via PARP activation and $\mathrm{NAD}(+)$ depletion is independent of the pathway leading to DNA fragmentation. Moreover, it seems that human BAT3 (HLA-B-associated transcript 3, Scynthe) [248] is an important regulator of ricin-dependent caspase-3-mediated apoptosis [215,221]. It interacts with ricin A-chain, which was confirmed by co-immunoprecipitation and confocal microscopy studies. BAT3 possesses at its C-terminal end, a canonical caspase-3 cleavage site, thus being the substrate for this protease. As a result of this cleavage, a 131 amino acid C-terminal fragment of BAT3 (CTF-131) is generated. It was observed that ricin-mediated induction of cell apoptosis by caspase-3 activation resulted in BAT3 cleavage after $4 \mathrm{~h}$ treatment with ricin. On the other hand, ricin-induced apoptosis was significantly reduced in cells with a decreased level of BAT3. Importantly, CTF-131 but not BAT3 was responsible for the observed direct ricin-induced apoptotic morphological changes such as: cell rounding, nuclear condensation, and phosphatidylserine exposure [221]. It was also observed that internalized ricin co-localized with endogenous BAT3 in the nuclei of HeLa cells. It was suggested that caspase-3-mediated proteolysis of BAT3 may require caspase- 3 translocation to the nucleus. Another important regulatory factor is the mitochondrial intramembrane protein AIF (apoptosis-inducing factor). BAT3 interacts with AIF in the cytosol [248], regulates its stability by inhibiting proteosomal degradation and also induces nuclear translocation of this factor. AIF may regulate caspase activation, however, after translocation to the nucleus, it is involved in chromatin condensation and DNA fragmentation [248].

As described above, the majority of experiments promote the idea that ricin initiates the intrinsic, mitochondrial-dependent pathway of apoptosis. However, some findings suggest that the extrinsic pathway might be also important in ricin-induced apoptosis. It has been demonstrated by TUNEL immunohistochemical staining, flow cytometry, and Western blotting that purified ricin A-chain was able to induce apoptosis in mouse embryonic fibroblast (NIH 3T3), by activation of caspase- 8 and -3 but not caspase-9 [222]. 


\subsubsection{Activation of Bcl-2 Family Members by Ricin}

Bcl-2 (B-cell lymphoma protein-2) family members regulate the intrinsic pathway of apoptosis. This family of proteins consists of three subfamilies playing opposing functions in this process: proapoptotic BH3-only members (Bim, Bid, Puma, Noxa, Hrk, Bmf, and Bad), proapoptotic effector molecules (Bax and Bak), and antiapoptotic Bcl-2 family proteins (Bcl-2, Bcl-xL, Mcl1, A1, and Bcl-B) $[244,245,249]$. It has been shown that overexpression of Bcl-2 improves the growth of MCF-7 breast cancer cells treated with ricin by 10-fold [223]. However, ricin retained its ability to inhibit protein synthesis in those cells. It has also been demonstrated that the ricin-induced apoptosis of hepatoma cells, BEL7404, results from increased expression of Bak and decreased levels of Bcl-xl and Bax [224]. However, overexpression of Bcl-2 can protect BEL7404 against ricin. These results are in agreement with other observations, supporting the view that signaling through mitochondria can represent the main mechanism of ricin-induced apoptosis. It is possible that in cells with an elevated level of Bcl-2, ricin-induced cell death is inhibited through titrating the function of its pro-apoptotic homologues, such as Bax. Consistent with these results, in cells overexpressing Bcl-2, a lower level of ricin-induced caspase- 3 activity and PARP cleavage were observed in comparison to control BEL7404 cells treated with ricin [224]. Interestingly, the use of a caspase-1-specific inhibitor also partially blocked ricin-induced apoptosis, implicating a role for caspase-1, and therefore possible involvement of the inflammasome and cytokine production in this process. Other studies showed that BER-40 cells (brefeldin A-resistant mutant cell line of Vero) were highly resistant to ricin-induced apoptosis as compared with their none-modified counterparts, parental Vero cells [225]. It was suggested that the function of mitochondria may be somehow altered in BER-40 since a lack of release of cytochrome $c$ was observed in these cells. However, the number and structure of mitochondria were not changed in these cells. Also, the expression level of Bcl-2 (which is the regulatory protein involved in the release of cytochrome c), was the same in Vero and BER-40 cells treated with ricin. Thus, it was suggested that relatively early apoptotic signaling pathways prior to those that lead to the release of cytochrome $\mathrm{C}$ may be altered in BER-40 cells. However, there is a possibility that mitochondria-related factors such as Bax and Bcl-xl, or the regulation of Bcl-2 activity by phosphorylation and dephosphorylation, might also be involved in the apoptosis resistance phenotype in BER-40 cells [225].

\subsubsection{Activation of Stress Associated Signaling Pathways by Ricin}

It has been proposed that the damage of the $28 \mathrm{~S}$ rRNA by ricin triggers a specific kinase-activated pathway termed the ribotoxic stress response (RSR) [226]. In this signaling pathway, stress-activated protein kinase SAPK/JNK1 (c-Jun N-terminal kinase) is activated together with its activator kinase SEK1/MKK4 [250]. It has been demonstrated that this activation does not result from the inhibition of protein synthesis, but is directly connected with signaling from the $28 \mathrm{~S}$ rRNA affected by ricin. JNKs, p38 and extracellular-receptor kinases (ERKs) belong to the Ser/Thr kinases termed MAPK (mitogen-activated protein kinase) family [251]. It is known that ricin can activate not only JNK, but also ERK and p38 MAPK in RAW 264.7 macrophages, and this is necessary for further activation of a variety of proinflammatory mediators [227]. Interestingly, not only ricin holotoxin but also high concentrations of ricin A-chain were able to induce both the p38 and JNK MAP kinase signaling pathways; however, signaling through the JNK kinase appeared to be more important in inducing the apoptotic response by RTA in the nontransformed epithelial cell line, MAC-T cells [219]. Ricin treatment induces the expression of proinflammatory cytokines and chemokines such as TNF- $\alpha$, interleukin (IL)-1, IL-6, and IL-8 [227-231]. It was demonstrated that macrophages and IL-1 signaling play a central role in the inflammatory process triggered by ricin [232]. Moreover, ricin is an activator of the NALP3 inflammasome, a scaffolding complex that mediates pro-IL-1 $\beta$ cleavage to active IL-1 $\beta$ by caspase-1 [233], (for review see also Ref. [234]). The proinflammatory response of ricin is believed to be initiated by phosphorylation of the kinase ZAK, a MAP3K, that is located upstream to the kinases p38 MAPK and JNK in a signal transduction pathway leading to proinflammatory gene expression [235]. It has been demonstrated that the JNK and p38 pathways regulate the expression of cytokines and 
downstream transcription factors in a different way [227]. The use of specific chemical inhibitors of the SAPK pathways in ricin-treated RAW 264.7 macrophages showed that suppression of the p38 pathway almost completely inhibited IL-1 $\alpha$ and $-\beta$ expression, while blocking the JNK pathway increased the expression of these cytokines. In contrast, inhibition of both pathways equally attenuated the ability of ricin to induce TNF- $\alpha$ gene expression [227]. Moreover, the role of p38 in ricin-induced expression of various proinflammatory genes was demonstrated [229], and chemical inhibition of the p38 pathway in the human monocyte/macrophage cell line 28SC blocked ricin-induced IL-8 secretion [228]. In addition, inhibition of the p38 MAPK pathway in ricin-treated RAW 264.7 macrophages attenuated both TNF- $\alpha$ secretion and apoptosis [236]. It was concluded that the ribotoxic stress response may trigger multiple signal transduction pathways through the activation of p38 MAP kinase. These results underline the major role of MAPK kinases and especially p38 in ricin-dependent regulation of apoptosis and in proinflammatory signals gene expression.

Besides MAPKs activation, ricin can also trigger the NF- $\mathrm{kB}$ pathway that is responsible for regulation of the expression of genes encoding inflammatory and pro-coagulant mediators $[215,230]$. It was suggested that the inhibition of protein synthesis by ricin may lead to the activation of NF- $\mathrm{kB}$. Moreover, the activation of both the JNK and p38 MAPK pathway as well as NF-kB occurs independently. Inhibition of TNF- $\alpha$ in cultured primary human airway epithelial cells did not prevent ricin-induced activation of NF- $\mathrm{KB}$ [230]. However, inhibition of NF- $\mathrm{KB}$ resulted in the release of cytochrome $\mathrm{c}$ from the mitochondria [252] and JNK1 kinase activation [252,253], suggesting an anti-apoptotic function of this transcription factor. The regulation of survival and apoptotic signals triggered by MAPKs and $\mathrm{NF}-\mathrm{kB}$ in response to ricin remains to be determined.

The second stress-associated signaling pathway affected by ricin is the unfolded protein response (UPR), which is related to the ER stress. This signaling pathway can be characterized as a cell reaction to the accumulation of unfolded or misfolded proteins in the lumen of the ER [122,124,159,254]. The UPR is regulated by three ER transmembrane receptors: the RNA-dependent protein kinase like ER kinase (PERK); the inositol-requiring ER to nucleus signal kinase-1 (IRE1) and the activating transcription factor-6 (ATF6) (for review see e.g., Refs. [124,255]). It has been demonstrated that ricin inhibits activation of the UPR in yeast by preventing Hac1 mRNA splicing [102]. The Hac1 mRNA is an important regulator of the IRE1 signaling pathway. Activated yeast Ire1p triggers unconventional splicing of the Hac1 mRNA leading to the synthesis of a transcription factor that specifically binds to promoters containing unfolded protein response elements [256]. Moreover, it was shown that RTA-mutated forms that could depurinate ribosomes but did not cause yeast cell death were unable to inhibit activation of the UPR by the ER stress-inducer tunicamycin [102]. These results suggest that the inability to activate the UPR in response to the ER stress contributes to the cytotoxicity of ricin. Other investigations also showed that ricin A-chain enhanced its own cytotoxicity by inhibiting the UPR [237]. In human epithelial cell lines (HeLa and MAC-T), RTA inhibited both phosphorylation of IRE1 and splicing of XBP1 mRNA (homologue of yeast Hac1) induced by tunicamycin. However, in contrast to these studies, it was demonstrated that ricin can activate PERK and ATF6 of the UPR pathways, but not the IRE1 branch [238]. This led to cell growth arrest and apoptosis. It was proposed that blocking of the UPR response allows RTA to trigger cell death through a mechanism that is independent of protein synthesis inhibition.

\subsubsection{Direct Action of Ricin on DNA and Ricin-Mediated Inhibition of DNA Repair Enzymes}

As already mentioned in this review, not only rRNA but also DNA is a ricin substrate in the catalytic reaction mediated by this toxin [212]. It has been demonstrated that ricin and other RIPs can act on DNA and many different polynucleotidic substrates, releasing adenine from the sugar phosphate backbone of poly- and polydeoxynucleotides [257]. It was even suggested that RIPs should be classified as polynucleotide:adenosine glycosidases. The nuclear DNA injury revealed in cultured cells by the alkaline-halo assay and the alkaline filter elution technique was attributed to adenine release from RNA-free chromatin [212] and naked DNA [257]. Interestingly, in the case of ricin, the DNA 
damage was observed very early after cells treatment with ricin, and this damage was concomitant with the protein synthesis inhibition. At this time, the annexin $\mathrm{V}$ binding assay, caspase- 3 activity, changes in cell morphology, and the formation of typical apoptotic DNA fragments were not detectable. It was suggested that ricin damages DNA in a way that does not result from ribosome inactivation or apoptosis [212] (Figure 4).

Ricin can also act indirectly on DNA by the inhibition of a DNA repair pathway. It has been demonstrated that this toxin, as well as other RIPs, releases an adenine from the ADP-ribosyl group of PARP [239]. NAD ${ }^{+}$-dependent auto ADP-ribosylation of PARP is necessary for its active involvement in the DNA repair pathway called base excision repair [258]. It was suggested that depurination of auto-modified PARP by ricin results not only in the inhibition of DNA repair, but also leads to further ADP-ribosylation of PARP and depletion of the intracellular levels of NAD ${ }^{+}$and ATP. This, together with the impaired repair of damaged DNA, would cause cell necrosis induced by lethal amounts of ricin [239]. Moreover, it has been reported that ricin can inhibit the repair of $\mathrm{H}_{2} \mathrm{O}_{2}$ and the alkylating agent methyl methane sulphonate (MMS)-induced DNA lesions in HUVEC and U937 cells [259]. The inhibition of DNA repair by ricin seems to result from direct interactions with the DNA repair machinery. Importantly, ricin concentration used in the experiments to inhibit DNA repair was not sufficient to cause direct DNA damage or to induce total protein synthesis inhibition.

\subsubsection{Ricin-Mediated Reactive Oxygen Species Production}

The production of the reactive oxygen species (ROS) in cells has been reported to be involved in apoptosis induction by activating signal transduction mechanisms located upstream of the caspase- 3 signalization pathway [260]. These pathways may be regulated by the changes in the oxidation status of the proteins involved in apoptosis signaling. It has been demonstrated that ricin increases the ROS levels in both yeast [24] and human cells [218]. The studies carried out on yeast suggested that the production of ROS is a necessary and sufficient condition for ricin-mediated induction of apoptosis [24]. Free radicals are scavenged by reduced glutathione (GSH). However, it was demonstrated in ricin-treated HeLa [218] and U937 cells [240] that the level of GSH was decreased. Thus, it was suggested that the GSH loss takes place downstream of caspase activation during the ricin-induced apoptotic process [240].

Interestingly, it has been demonstrated that the ROS formation is dependent on the presence of both extracellular and intracellular $\mathrm{Ca}^{2+}$ [261]. A rapid elevation of cellular calcium levels was observed in ricin-treated hepatoma cells [224]. Madin-Darby Canine Kidney (MDCK) cell death was significantly blocked by 1,9-deoxyforskolin (DDF) treatment, a drug that can reduce ion flux through several ion channels. This protective effect was significantly reversed by the increase in the extracellular $\mathrm{Ca}^{2+}$ concentrations [241].

Ricin-induced apoptosis is correlated not only with the elevation of the level of calcium ions. It was demonstrated that in ricin-treated U937 cells, the level of intracellular $\mathrm{Zn}^{2+}$ was increased and zinc was much more redistributed into the cytosol [242]. This occurs as an early apoptotic event, and exogenously-added $\mathrm{Zn}^{2+}$ inhibited the ricin-induced apoptosis. It was suggested that $\mathrm{Zn}^{2+}$ ions play a regulatory role in ricin-mediated apoptosis through their dissociation/association with certain intracellular elements.

\subsubsection{Ricin B-Chain-Induced Apoptosis}

Studies carried on U937 cells have demonstrated that the interaction of ricin B-chain with membrane glycoproteins and glycolipids may trigger signaling events leading to apoptosis [33]. This lectin activity-dependent mechanism was distinct from apoptosis signaling pathways induced by ricin A-chain. It has been demonstrated that carboxymethylated-(CM-) ricin B-chain was responsible for DNA fragmentation and typical apoptotic nuclear morphological changes, which were very similar to those observed in ricin-treated cells [33]. CM-ricin B-chain failed to inhibit protein synthesis in U937 cells. Thus, these experiments support the hypothesis that ricin-induced apoptosis or at least some of the apoptotic pathways are independent and not correlated with protein synthesis inhibition, at 
least in U937 cells. Recently published results have also shown that ricin-induced apoptosis is not solely attributed to the A-chain [243]. The intact heterodimeric ricin and ricin chains were injected into rats in order to study ricin-induced apoptosis in liver, which is a major site of in vivo ricin uptake and cytotoxicity [262]. It has been demonstrated that ricin was responsible for the intrinsic apoptosis pathway since increased cytochrome c content, activation of caspase- 9 and caspase-3, and enrichment of DNA fragments in the cytosol were observed [243]. These authors observed also the B-chain in the cytosol and reported that it caused cytochrome $\mathrm{c}$ release from mitochondria in vivo and in vitro. These results suggest that a direct interaction of ricin B-chain with the mitochondrial outer membrane can be involved in ricin-induced apoptosis. The involvement of recombinant RTB in macrophage activation has also been studied [263]. It was demonstrated that RTB stimulated inducible nitric oxide (NO) synthase (iNOS) and TNF- $\alpha$ and IL-6 expression, which are involved in the activation of protein tyrosine kinase, NF- $\mathrm{kB}$ and JAK-STAT signaling.

\section{Perspectives}

\subsection{Ricin-Based Immunotoxins}

In the 19th century, Paul Ehrlich proposed the "magic bullet concept", which states that drugs can directly enter target cells and hit only abnormal cells of the human body [264]. Since then, the idea of a selective action of drugs that are able to affect only specific types of cells has been dynamically developed. However, the specificity of this process is challenging. The concept is utilized particularly in the field of cancer therapy with the application of immunotoxins (ITs) [265-268]. ITs are chimeric proteins composed of a toxin or a part of the toxin conjugated with a monoclonal antibody $(\mathrm{mAb})$ or its fragment. When toxins are coupled to other carriers: growth factors, hormones or lectins that preferentially bind to some cell types, they are more commonly referred to as "chimeric toxins" or "conjugates" [269]. Ricin is the most commonly used plant toxin in the construction of ITs [30,269]. The first ricin-based ITs were prepared by binding holotoxin to a specific mAb [270]. Despite high efficiency, a large non-specific toxic effect of these immunotoxins was observed and made them impossible to use in a clinical setting. In a different experimental approach, only the A-chain of ricin was used, but also such ITs exhibited non-specific toxicity [271], due to the fact that receptors present on many cell types can recognize mannose residues present on the RTA [272]. To solve this problem, new ITs were prepared with deglycosylated RTA (dgRTA) [269,273,274].

Ricin-based immunotoxins are promising in the treatment of many types of diseases. Autoimmunity, immunodeficiency and neoplasia are examples of diseases connected with deregulation of the immune system. These dysfunctions are characterized by changes in the normal amount or function of Th (helper) cells. ITs composed of RTA and cell-reactive antibodies can specifically target neoplastic cells. It was shown that treatment of Th cells with Fab' fragments of anti-L3T4 antibody bound with RTA (Fab'anti-L3T4-A) inhibit keyhole limpet hemocyanin (KLH)-specific Th cells from proliferation and differentiation of the antigen-specific B cells (trinitrophenyl-(TNP)-specific B cells) [275]. These results indicate that Fab'anti-L3T4-A is able to specially inhibit Th cells that activate B cells. Another immunotoxin RTA-4D5-KDEL was constructed by connecting the anti-HER2 single chain variable fragment $4 \mathrm{D} 5 \mathrm{scFv}$ and $\mathrm{KDEL}$, the ER-targeting peptides, with the C-terminal part of the RTA. Experiments showed that RTA-4D5-KDEL had a strong inhibitory effect on the ovarian cancer cells, SKOV-3, which were HER-2 overexpressing, and caused little damage to H460 lung cancer cells and to kidney HEK 293 cells. The KDEL of the RTA-4D5-KDEL immunotoxin was able to direct the recombinant protein to the ER. In light of this information, it can be assumed that this immunotoxin has a strong inhibitory effect on ovarian cancer cells with overexpression of HER2, and that it will exhibit little toxicity in normal cells [44]. Bladder cancer is one of the most frequent tumors. This disease is treated with transurethral resections and additionally with local immunotherapy or chemotherapy with good results; however, there is no ideal therapy to heal invasive carcinoma. A new antibody-based immunotoxin BCMab1-Ra was generated by linking of BCMab1-, a novel mouse 
monoclonal antibody, specific for aberrantly glycosylated Integrin a3b1 in this type of cancer with the ricin A-chain (Ra) [276]. The effect of the BCMab1-Ra on bladder cancer was investigated on a 57-year-old patient that refused radical surgery and chemotherapy. It has been demonstrated that the use of BCMab1-Ra first reduced the tumor, and that after 30 weeks of treatment there was no tumor observed by cystoscope examination. Moreover, human anti-mouse antibody (HAMA) that would indicate a strong immunologic response was not detectable in the blood circulation of this patient [276].

Various therapies are being utilized in the treatment of cancer. Traditional procedures such as radiation therapy, chemotherapy and surgery have some limitations and give serious side effects. Immunotoxins represent another technique with the possibility to increase the selectivity of action, but further development in this field is required.

\subsection{Ricin Conjugated with Nanoparticles}

During recent years, nanoparticles (NPs) have been studied intensively both as carriers used for delivery of therapeutic drugs (conventional drugs, recombinant proteins, vaccines and nucleotides) to certain cells and as therapeutic agents that may act per se or modulate activity of other compounds [277-280]. One carrier that can deliver (NPs) to cells is the ricin B-chain. The internalization mechanism as well as intracellular transport of ricinB:Quantum dot (QD) nanoparticle conjugates have been studied in different cells [41,281,282]. It was concluded that Qdots may have severe consequences on cell physiology [281,282]. Moreover, the internalization of ricinB:QDs in HeLa cells is dependent on dynamin and based on a macropinocytosis-like mechanism [41].

A complex of carbon dots (CDs) with RTB has been evaluated for enhanced immunomodulatory activity of RTB [283]. It was demonstrated that CDs-RTB can facilitate macrophage proliferation and increase the generation of nitric oxide (NO), IL-6 and TNF- $\alpha$ in RAW 264.7 cells, indicating enhanced immunomodulatory activity of CDs-RTB in comparison to RTB acting alone [283].

Another interesting example is a recombinant version of a ricin nanoparticle (T22-mRTA-H6) containing the T22 peptide, an efficient ligand of the cell surface marker CXCR4 (a cytokine receptor selectively overexpressed in metastatic cells of many cancer types) at the amino terminus followed by a mutated version of the ricin A chain and a hexahistidine tail at the carboxy terminus [284]. In this construct, mutation N132A was introduced to suppress the vascular leak syndrome (see below); a furin cleavage site was incorporated to allow the release of the $\mathrm{N}$-terminal region in the endosome as well as a KDEL motif was added to mediate retrograde transport. Interestingly, this construct was engineered in order to allow for ricin A-chain aggregation and to become a targeting agent for the precise tumor delivery of protein-only nanoparticles. The recombinant T22-mRTA-H6 was produced in E. coli and purified. The spontaneous formation of self-assembled nanoparticles was possibly due to the combination of the cationic peptides at the amino terminus and polyhistidines at the carboxy terminus. T22-mRTA-H6 nanoparticles show highly selective therapeutic effects, and ricin A-chain was highly active on target cells, significantly reducing the effect of leukemia cells on relevant organs.

\subsection{Vaccines against Ricin and Neutralizing Antibodies against Ricin}

Despite numerous medical applications in which ricin can be used, this toxin is among the most potent and lethal substances that are known $[35,285]$. Currently, no approved vaccine or therapeutics exist to protect against ricin intoxication. The idea to develop a preventive vaccine against ricin has grown over the last years mainly because of the increasing concern that crude ricin powder can easily be made and used as a bio-threat agent. Two of the leading vaccine antigen candidates, the closely related RTA-based subunit vaccines, $\operatorname{RiVax}^{\mathrm{TM}}$ and $\operatorname{RVEc}^{\mathrm{TM}}$, are now under development $[39,286,287]$. $\operatorname{RiVax}^{\mathrm{TM}}$ is a full-length recombinant derivative of RTA whose enzymatic activity has been largely eliminated through a point mutation in a key active site residue (Y80A). RiVax ${ }^{\mathrm{TM}}$ also contains a mutation in the site (V76M) attributed to the induction of the vascular leak syndrome (VLS) [286]. The VLS is the main side-effect of ricin-derived immunotoxins. It has a complex etiology involving damage to vascular endothelial cells [288]. Mutation in the vaccine to alter the VLS motif was introduced to eliminate 
this toxicity. $\mathrm{RVEc}^{\mathrm{TM}}$ is a truncated derivative of RTA that lacks the hydrophobic carboxy-terminal region (residues 199-267) as well as a small hydrophobic loop in the $\mathrm{N}$-terminus (residues 34-43). $\mathrm{RVEc}^{\mathrm{TM}}$ mutations do not directly influence the active site of RTA, but the removal of both regions causes that ricin present in this vaccine is inactive with reduced ability to cause the vascular leak syndrome $[39,287]$. Both candidate vaccines are under investigation in animal studies and Phase I clinical trials. Furthermore, the results of two Phase I clinical trials have indicated that RiVax ${ }^{\mathrm{TM}}$ is safe and immunogenic in humans $[289,290]$. One obvious strategy to augment the overall immunogenicity of vaccines is the use of next-generation adjuvants. However, adjuvants themselves may not be sufficient to achieve maximal immunogenicity. Enhancing the immunogenicity of vaccines may require a structure-based redesign of the antigen itself. The resulting combinations of mutations led to the identification of derivatives of RiVax which are several times more efficient [291].

In the late 1880s, Paul Erhlich and others first described the potential use of antibodies (Abs) to completely inactivate the toxin. Immunity to ricin is associated with the production of protective antibodies. Since those early studies, many studies of antisera and antibody preparations derived from different animal species and tested on a diversity of cell types have been made. Anti-RTA and RTB antibodies were tested in rabbits and mice and displayed some neutralization action. Some results suggest that antibodies neutralize ricin by perturbing toxin uptake and/or intracellular trafficking without affecting the toxin attachment to cell surfaces. This confers passive immunity in vivo [37,291-293]. On the other hand, blocking ricin attachment to receptors on the cell surface is the mechanisms of action of other specific antibodies (24B11 and VHH D10/B7) [294]. Multiple studies revealed that there are three general classes of ricin-specific Abs; those that bind RTA, RTB and ricin holotoxin [286,295]. As part of an effort to engineer ricin antitoxin and immunotherapies, libraries of phage-displayed, heavy chain-only antibodies $\left(\mathrm{V}_{\mathrm{H}} \mathrm{Hs}\right)$ have been produced and well characterized [296]. It has been demonstrated that immunity against ricin is mediated by antibody. However, the specificity of particular epitopes involved in protective immunity remains unclear. The importance of toxin-neutralizing antibodies in protection against ricin is not questioned. However, the exact correlation between the structure of RTA and the induction of protective immunity must be more strictly evaluated. In just the past 10 years, several reports have been published that demonstrated that passive administration of a toxin-neutralizing antibody is sufficient to display mice protection to a lethal dose of ricin delivered by injection, ingestion or inhalation [292,297-301].

\section{Concluding Remarks}

Ricin can be considered as a powerful tool to study intracellular pathways in general and cell death mechanisms that include apoptosis, inflammation or cell stress-induced signaling. On the other hand, exact knowledge about ricin action in the target cells is necessary to produce effectively working ricin-based immunotoxins or vaccines. One of the most interesting discoveries that has been made recently describes a vital sugar code for ricin toxicity, that is conserved from mouse to human [100]. This mechanism is based on defined glycosidic structures that determine cellular fate upon exposure to the toxin. The question of whether depurination of rRNA is necessary for ricin-induced cell death is still being discussed. It is believed that in addition to rRNA damage, ricin can induce apoptosis, inflammation and DNA damage. The correlation between these processes has been intensively studied. This knowledge is constantly being expanded as the huge contribution to this field has been made over the past years. An old dogma about ricin has currently been investigated. It was believed that a single A-chain molecule of ricin or other type-2 RIPs have the ability to kill one eukaryotic cell [20]. However, it was recently reported that one or a few molecules of ricin A-chain present in the cytosol is not sufficient to inhibit protein synthesis [302]. Moreover, cells with a partial inhibition of protein synthesis can, upon ricin removal, increase the level of protein production and survive the toxin challenge. Thus, in contrast to the previously accepted model, ongoing toxin delivery to the cytosol appears to be necessary for the death of cells exposed to sub-optimal ricin concentrations [302]. It was also suggested that ricin and other RIPs can be more toxic to cancer cells than to normal cells, due to the 
higher rate of protein synthesis in malignant cells during proliferation or due to the changes in receptor concentration on their surfaces or altered intracellular transport of the toxin [30,42,303-305]. This is, however, not always the case (for review see e.g., Refs. [30,285]). Thus, for specific delivery of ricin to cancer cells, directing ricin to particular epitopes on tumor cells is necessary. On the other hand, some specific properties of ricin may enhance its effect on cancer cells. The ability of RTA to inhibit UPR may make it more potent in targeted therapy for cancer. It has been demonstrated that an increased level of spliced XBP1 relatively to unspliced XBP1 correlates with poor prognosis in breast cancer [306], and $\mathrm{XBP1}$ has been proposed as a therapeutic target for solid tumors [307]. Thus, ricin treatment may be particularly useful in cancer cells where UPR is already accelerated by conditions such as hypoxia. These findings highlight the role of ricin as a valuable component of modern immunotoxins.

Funding: The work referred to as from the Słomińska-Wojewódzka group was supported by the National Science Centre Poland grant 2015/19/B/NZ3/03266. Work with toxins in the group of Sandvig is supported by the Norwegian Cancer Society and the Southern and Eastern Norway Regional Health Authority.

Conflicts of Interest: The authors declare no conflict of interest.

\section{References}

1. Stillmark, H. Ueber Ricin, ein giftiges Ferment aus den Samen von Ricinus comm. L. und einigen anderen Euphorbiaceen: Inaugural-Dissertation. MD Thesis, University of Dorpat, Dorpat, Estonia, 1888.

2. Boyd, W.C.; Shapleigh, E. Diagnosis by subgroups of blood groups A and AB by use of plant agglutinins (lectins). J. Lab. Clin. Med. 1954, 44, 235-237. [PubMed]

3. Olsnes, S.; Pihl, A. Ricin-A potent inhibitor of protein synthesis. FEBS Lett. 1972, 20, 327-329. [CrossRef]

4. Olsnes, S.; Pihl, A. Different biological properties of the two constituent peptide chains of ricin, a toxic protein inhibiting protein synthesis. Biochemistry 1973, 12, 3121-3126. [CrossRef] [PubMed]

5. Olsnes, S.; Heiberg, R.; Pihl, A. Inactivation of eucaryotic ribosomes by the toxic plant proteins abrin and ricin. Mol. Biol. Rep. 1973, 1, 15-20. [CrossRef] [PubMed]

6. Endo, Y.; Tsurugi, K. RNA N-glycosidase activity of ricin A-chain. Mechanism of action of the toxic lectin ricin on eukaryotic ribosomes. J. Biol. Chem. 1987, 262, 8128-8130.

7. Endo, Y.; Mitsui, K.; Motizuki, M.; Tsurugi, K. The mechanism of action of ricin and related toxic lectins on eukaryotic ribosomes. The site and the characteristics of the modification in $28 \mathrm{~S}$ ribosomal RNA caused by the toxins. J. Biol. Chem. 1987, 262, 5908-5912.

8. Lord, J.M.; Roberts, L.M.; Robertus, J.D. Ricin: Structure, mode of action, and some current applications. FASEB J. 1994, 8, 201-208. [CrossRef]

9. Olsnes, S.; Refsnes, K.; Pihl, A. Mechanism of action of the toxic lectins abrin and ricin. Nature 1974, 249, 627-631. [CrossRef]

10. Shi, W.-W.; Mak, A.N.-S.; Wong, K.-B.; Shaw, P.-C. Structures and Ribosomal Interaction of Ribosome-Inactivating Proteins. Molecules 2016, 21, 1588. [CrossRef]

11. Zhou, Y.; Li, X.-P.; Kahn, J.N.; Tumer, N.E. Functional Assays for Measuring the Catalytic Activity of Ribosome Inactivating Proteins. Toxins 2018, 10, 240. [CrossRef]

12. Barbieri, L.; Battelli, M.G.; Stirpe, F. Ribosome-inactivating proteins from plants. Biochim. Biophys. Acta 1993, 1154, 237-282. [CrossRef]

13. Voorhees, R.M.; Schmeing, T.M.; Kelley, A.C.; Ramakrishnan, V. The mechanism for activation of GTP hydrolysis on the ribosome. Science 2010, 330, 835-838. [CrossRef] [PubMed]

14. Shi, X.; Khade, P.K.; Sanbonmatsu, K.Y.; Joseph, S. Functional role of the sarcin-ricin loop of the $23 \mathrm{~S}$ rRNA in the elongation cycle of protein synthesis. J. Mol. Biol. 2012, 419, 125-138. [CrossRef] [PubMed]

15. Lancaster, L.; Lambert, N.J.; Maklan, E.J.; Horan, L.H.; Noller, H.F. The sarcin-ricin loop of 23S rRNA is essential for assembly of the functional core of the 50S ribosomal subunit. RNA 2008, 14, 1999-2012. [CrossRef] [PubMed]

16. Moazed, D.; Robertson, J.M.; Noller, H.F. Interaction of elongation factors EF-G and EF-Tu with a conserved loop in 23S RNA. Nature 1988, 334, 362-364. [CrossRef] [PubMed]

17. Hartley, M.R.; Lord, J.M. Cytotoxic ribosome-inactivating lectins from plants. Biochim. Biophys. Acta 2004, 1701, 1-14. [CrossRef] [PubMed] 
18. Olsnes, S.; Fernandez-Puentes, C.; Carrasco, L.; Vazquez, D. Ribosome inactivation by the toxic lectins abrin and ricin. Kinetics of the enzymic activity of the toxin A-chains. Eur. J. Biochem. 1975, 60, 281-288. [CrossRef] [PubMed]

19. Olsnes, S. The history of ricin, abrin and related toxins. Toxicon 2004, 44, 361-370. [CrossRef] [PubMed]

20. Eiklid, K.; Olsnes, S.; Pihl, A. Entry of lethal doses of abrin, ricin and modeccin into the cytosol of HeLa cells. Exp. Cell Res. 1980, 126, 321-326. [CrossRef]

21. Olson, K.R. Poisoning and Drug Overdose, Sixth Edition, 6th ed.; McGraw-Hill Education/Medical: New York, NY, USA, 2011; ISBN 978-0-07-166833-0.

22. Moshiri, M.; Hamid, F.; Etemad, L. Ricin Toxicity: Clinical and Molecular Aspects. Rep. Biochem. Mol. Biol. 2016, 4, 60-65.

23. Convention on the Prohibition of the Development, Production, Stockpiling and Use of Chemical Weapons and on Their Destruction; Organisation for the Probhibition of Chemical Weapons (OPCW): The Hague, The Netherlands, 2005.

24. Li, X.-P.; Baricevic, M.; Saidasan, H.; Tumer, N.E. Ribosome depurination is not sufficient for ricin-mediated cell death in Saccharomyces cerevisiae. Infect. Immun. 2007, 75, 417-428. [CrossRef] [PubMed]

25. Flexner, S. The histological changes produced by ricin and abrin intoxications. J. Exp. Med. 1897, 2, 197-216. [CrossRef] [PubMed]

26. Griffiths, G.D.; Leek, M.D.; Gee, D.J. The toxic plant proteins ricin and abrin induce apoptotic changes in mammalian lymphoid tissues and intestine. J. Pathol. 1987, 151, 221-229. [CrossRef] [PubMed]

27. Hughes, J.N.; Lindsay, C.D.; Griffiths, G.D. Morphology of ricin and abrin exposed endothelial cells is consistent with apoptotic cell death. Hum. Exp. Toxicol. 1996, 15, 443-451. [CrossRef] [PubMed]

28. Day, P.J.; Pinheiro, T.J.T.; Roberts, L.M.; Lord, J.M. Binding of ricin A-chain to negatively charged phospholipid vesicles leads to protein structural changes and destabilizes the lipid bilayer. Biochemistry 2002, 41, 2836-2843. [CrossRef] [PubMed]

29. Kumar, O.; Sugendran, K.; Vijayaraghavan, R. Oxidative stress associated hepatic and renal toxicity induced by ricin in mice. Toxicon 2003, 41, 333-338. [CrossRef]

30. Słomińska-Wojewódzka, M.; Sandvig, K. Ricin and Ricin-Containing Immunotoxins: Insights into Intracellular Transport and Mechanism of action in Vitro. Antibodies 2013, 2, 236-269. [CrossRef]

31. Shih, S.-F.; Wu, Y.-H.; Hung, C.-H.; Yang, H.-Y.; Lin, J.-Y. Abrin Triggers Cell Death by Inactivating a Thiol-specific Antioxidant Protein. J. Biol. Chem. 2001, 276, 21870-21877. [CrossRef] [PubMed]

32. Baluna, R.; Coleman, E.; Jones, C.; Ghetie, V.; Vitetta, E.S. The Effect of a Monoclonal Antibody Coupled to Ricin A Chain-Derived Peptides on Endothelial Cells in Vitro: Insights into Toxin-Mediated Vascular Damage. Exp. Cell Res. 2000, 258, 417-424. [CrossRef]

33. Hasegawa, N.; Kimura, Y.; Oda, T.; Komatsu, N.; Muramatsu, T.H.-J. Isolated ricin B-chain-mediated apoptosis in U937 cells. Biosci. Biotechnol. Biochem. 2000, 64, 1422-1429. [CrossRef]

34. Berger, T.; Eisenkraft, A.; Bar-Haim, E.; Kassirer, M.; Aran, A.A.; Fogel, I. Toxins as biological weapons for terror-characteristics, challenges and medical countermeasures: A mini-review. Disaster Mil. Med. 2016, 2, 7. [CrossRef] [PubMed]

35. Janik, E.; Ceremuga, M.; Saluk-Bijak, J.; Bijak, M. Biological Toxins as the Potential Tools for Bioterrorism. Int. J. Mol. Sci. 2019, 20, 1181. [CrossRef] [PubMed]

36. Hu, W.; Yin, J.; Chau, D.; Hu, C.C.; Cherwonogrodzky, J.W. Anti-Ricin Protective Monoclonal Antibodies. Ricin Toxin 2014, 14, 145-158.

37. Herrera, C.; Klokk, T.I.; Cole, R.; Sandvig, K.; Mantis, N.J. A Bispecific Antibody Promotes Aggregation of Ricin Toxin on Cell Surfaces and Alters Dynamics of Toxin Internalization and Trafficking. PLoS ONE 2016, 11, e0156893. [CrossRef]

38. Yermakova, A.; Klokk, T.I.; O’Hara, J.M.; Cole, R.; Sandvig, K.; Mantis, N.J. Neutralizing Monoclonal Antibodies against Disparate Epitopes on Ricin Toxin's Enzymatic Subunit Interfere with Intracellular Toxin Transport. Sci. Rep. 2016, 6, 22721. [CrossRef] [PubMed]

39. Brey, R.N.; Mantis, N.J.; Pincus, S.H.; Vitetta, E.S.; Smith, L.A.; Roy, C.J. Recent advances in the development of vaccines against ricin. Hum. Vaccin Immunother. 2016, 12, 1196-1201. [CrossRef] [PubMed]

40. Liu, X.; Pop, L.M.; Schindler, J.; Vitetta, E.S. Immunotoxins constructed with chimeric, short-lived anti-CD22 monoclonal antibodies induce less vascular leak without loss of cytotoxicity. MAbs 2012, 4, 57-68. [CrossRef] [PubMed] 
41. Iversen, T.G.; Frerker, N.; Sandvig, K. Uptake of ricinB-quantum dot nanoparticles by a macropinocytosis-like mechanism. J. Nanobiotechnol. 2012, 10, 33. [CrossRef] [PubMed]

42. Tyagi, N.; Tyagi, M.; Pachauri, M.; Ghosh, P.C. Potential therapeutic applications of plant toxin-ricin in cancer: Challenges and advances. Tumor Biol. 2015, 36, 8239-8246. [CrossRef]

43. Pizzo, E.; Di Maro, A. A new age for biomedical applications of Ribosome Inactivating Proteins (RIPs): From bioconjugate to nanoconstructs. J. Biomed Sci. 2016, 23, 54. [CrossRef]

44. Jiao, P.; Zhang, J.; Dong, Y.; Wei, D.; Ren, Y. Construction and characterization of the recombinant immunotoxin RTA-4D5-KDEL targeting HER2/neu-positive cancer cells and locating the endoplasmic reticulum. Appl. Microbiol. Biotechnol. 2018, 102, 9585-9594. [CrossRef]

45. Magnusson, S.; Kjeken, R.; Berg, T. Characterization of two distinct pathways of endocytosis of ricin by rat liver endothelial cells. Exp. Cell Res. 1993, 205, 118-125. [CrossRef]

46. Sphyris, N.; Lord, J.M.; Wales, R.; Roberts, L.M. Mutational analysis of the Ricinus lectin B-chains. Galactose-binding ability of the 2 gamma subdomain of Ricinus communis agglutinin B-chain. J. Biol. Chem. 1995, 270, 20292-20297. [CrossRef] [PubMed]

47. Sandvig, K.; Olsnes, S.; Pihl, A. Kinetics of binding of the toxic lectins abrin and ricin to surface receptors of human cells. J. Biol. Chem. 1976, 251, 3977-3984.

48. Sandvig, K.; Spilsberg, B.; Lauvrak, S.U.; Torgersen, M.L.; Iversen, T.-G.; van Deurs, B.O. Pathways followed by protein toxins into cells. Int. J. Med. Microbiol. 2004, 293, 483-490. [CrossRef] [PubMed]

49. Van Deurs, B.; Pedersen, L.R.; Sundan, A.; Olsnes, S.; Sandvig, K. Receptor-mediated endocytosis of a ricin-colloidal gold conjugate in vero cells. Intracellular routing to vacuolar and tubulo-vesicular portions of the endosomal system. Exp. Cell Res. 1985, 159, 287-304. [CrossRef]

50. Moya, M.; Dautry-Varsat, A.; Goud, B.; Louvard, D.; Boquet, P. Inhibition of coated pit formation in Hep2 cells blocks the cytotoxicity of diphtheria toxin but not that of ricin toxin. J. Cell Biol. 1985, 101, 548-559. [CrossRef] [PubMed]

51. Sandvig, K.; Olsnes, S.; Petersen, O.W.; van Deurs, B. Inhibition of endocytosis from coated pits by acidification of the cytosol. J. Cell. Biochem. 1988, 36, 73-81. [CrossRef] [PubMed]

52. Simpson, J.C.; Smith, D.C.; Roberts, L.M.; Lord, J.M. Expression of mutant dynamin protects cells against diphtheria toxin but not against ricin. Exp. Cell Res. 1998, 239, 293-300. [CrossRef]

53. Spooner, R.A.; Lord, J.M. Ricin Trafficking in Cells. Toxins 2015, 7, 49-65. [CrossRef] [PubMed]

54. Rodal, S.K.; Skretting, G.; Garred, O.; Vilhardt, F.; van Deurs, B.; Sandvig, K. Extraction of cholesterol with methyl-beta-cyclodextrin perturbs formation of clathrin-coated endocytic vesicles. Mol. Biol. Cell 1999, 10, 961-974. [CrossRef] [PubMed]

55. Sandvig, K.; Pust, S.; Skotland, T.; van Deurs, B. Clathrin-independent endocytosis: Mechanisms and function. Curr. Opin. Cell Biol. 2011, 23, 413-420. [CrossRef] [PubMed]

56. Sandvig, K.; Kavaliauskiene, S.; Skotland, T. Clathrin-independent endocytosis: An increasing degree of complexity. Histochem. Cell Biol. 2018, 150, 107-118. [CrossRef] [PubMed]

57. Sandvig, K.; Grimmer, S.; Iversen, T.G.; Rodal, K.; Torgersen, M.L.; Nicoziani, P.; van Deurs, B. Ricin transport into cells: Studies of endocytosis and intracellular transport. Int. J. Med. Microbiol. 2000, 290, 415-420. [CrossRef]

58. Sokołowska, I.; Wälchli, S.; Węgrzyn, G.; Sandvig, K.; Słomińska-Wojewódzka, M. A single point mutation in ricin A-chain increases toxin degradation and inhibits EDEM1-dependent ER retrotranslocation. Biochem. J. 2011, 436, 371-385. [CrossRef]

59. Sokołowska, I.; Piłka, E.S.; Sandvig, K.; Węgrzyn, G.; Słomińska-Wojewódzka, M. Hydrophobicity of protein determinants influences the recognition of substrates by EDEM1 and EDEM2 in human cells. BMC Cell Biol. 2015, 16, 1. [CrossRef]

60. Becker, B.; Schnöder, T.; Schmitt, M.J. Yeast Reporter Assay to Identify Cellular Components of Ricin Toxin A Chain Trafficking. Toxins 2016, 8, 366. [CrossRef]

61. Lewis, M.J.; Pelham, H.R.B. A new yeast endosomal SNARE related to mammalian syntaxin 8. Traffic 2002, 3 , 922-929. [CrossRef]

62. Tang, H.; Song, M.; He, Y.; Wang, J.; Wang, S.; Shen, Y.; Hou, J.; Bao, X. Engineering vesicle trafficking improves the extracellular activity and surface display efficiency of cellulases in Saccharomyces cerevisiae. Biotechnol. Biofuels 2017, 10, 53. [CrossRef] 
63. Sandvig, K.; Olsnes, S.; Pihl, A. Interactions between abrus lectins and Sephadex particles possessing immobilized desialylated fetuin. Model studies of the interaction of lectins with cell surface receptors. Eur. J. Biochem. 1978, 88, 307-313. [CrossRef]

64. Blum, J.S.; Fiani, M.L.; Stahl, P.D. Proteolytic cleavage of ricin A chain in endosomal vesicles. Evidence for the action of endosomal proteases at both neutral and acidic pH. J. Biol. Chem. 1991, 266, 22091-22095. [PubMed]

65. Sandvig, K.; van Deurs, B. Membrane traffic exploited by protein toxins. Annu. Rev. Cell Dev. Biol. 2002, 18, 1-24. [CrossRef] [PubMed]

66. Van Deurs, B.; Tønnessen, T.I.; Petersen, O.W.; Sandvig, K.; Olsnes, S. Routing of internalized ricin and ricin conjugates to the Golgi complex. J. Cell Biol. 1986, 102, 37-47. [CrossRef] [PubMed]

67. Van Deurs, B.; Sandvig, K.; Petersen, O.W.; Olsnes, S.; Simons, K.; Griffiths, G. Estimation of the amount of internalized ricin that reaches the trans-Golgi network. J. Cell Biol. 1988, 106, 253-267. [CrossRef] [PubMed]

68. Sandvig, K.; van Deurs, B. Delivery into cells: Lessons learned from plant and bacterial toxins. Gene Ther. 2005, 12, 865-872. [CrossRef] [PubMed]

69. Rapak, A.; Falnes, P.O.; Olsnes, S. Retrograde transport of mutant ricin to the endoplasmic reticulum with subsequent translocation to cytosol. Proc. Natl. Acad. Sci. USA 1997, 94, 3783-3788. [CrossRef]

70. Driouich, A.; Zhang, G.F.; Staehelin, L.A. Effect of brefeldin A on the structure of the Golgi apparatus and on the synthesis and secretion of proteins and polysaccharides in sycamore maple (Acer pseudoplatanus) suspension-cultured cells. Plant Physiol. 1993, 101, 1363-1373. [CrossRef]

71. Yoshida, T.; Chen, C.C.; Zhang, M.S.; Wu, H.C. Disruption of the Golgi apparatus by brefeldin A inhibits the cytotoxicity of ricin, modeccin, and Pseudomonas toxin. Exp. Cell Res. 1991, 192, 389-395. [CrossRef]

72. Sandvig, K.; Prydz, K.; Hansen, S.H.; van Deurs, B. Ricin transport in brefeldin A-treated cells: Correlation between Golgi structure and toxic effect. J. Cell Biol. 1991, 115, 971-981. [CrossRef]

73. Prydz, K.; Hansen, S.H.; Sandvig, K.; van Deurs, B. Effects of brefeldin A on endocytosis, transcytosis and transport to the Golgi complex in polarized MDCK cells. J. Cell Biol. 1992, 119, 259-272. [CrossRef]

74. Leitinger, B.; Brown, J.L.; Spiess, M. Tagging secretory and membrane proteins with a tyrosine sulfation site. Tyrosine sulfation precedes galactosylation and sialylation in COS-7 cells. J. Biol. Chem. 1994, 269, 8115-8121.

75. Llorente, A.; Rapak, A.; Schmid, S.L.; van Deurs, B.; Sandvig, K. Expression of Mutant Dynamin Inhibits Toxicity and Transport of Endocytosed Ricin to the Golgi Apparatus. J. Cell Biol. 1998, 140, 553-563. [CrossRef] [PubMed]

76. Gray, J.L.; von Delft, F.; Brennan, P. Targeting the Small GTPase Superfamily through their Regulatory Proteins. Angew. Chem. Int. Ed. 2019. [CrossRef]

77. Lombardi, D.; Soldati, T.; Riederer, M.A.; Goda, Y.; Zerial, M.; Pfeffer, S.R. Rab9 functions in transport between late endosomes and the trans Golgi network. EMBO J. 1993, 12, 677-682. [CrossRef] [PubMed]

78. Riederer, M.A.; Soldati, T.; Shapiro, A.D.; Lin, J.; Pfeffer, S.R. Lysosome biogenesis requires Rab9 function and receptor recycling from endosomes to the trans-Golgi network. J. Cell Biol 1994, 125, 573-582. [CrossRef] [PubMed]

79. Iversen, T.G.; Skretting, G.; Llorente, A.; Nicoziani, P.; van Deurs, B.; Sandvig, K. Endosome to Golgi transport of ricin is independent of clathrin and of the Rab9- and Rab11-GTPases. Mol. Biol. Cell 2001, 12, 2099-2107. [CrossRef]

80. Mallard, F.; Tang, B.L.; Galli, T.; Tenza, D.; Saint-Pol, A.; Yue, X.; Antony, C.; Hong, W.; Goud, B.; Johannes, L. Early/recycling endosomes-to-TGN transport involves two SNARE complexes and a Rab6 isoform. J. Cell Biol. 2002, 156, 653-664. [CrossRef] [PubMed]

81. Echard, A.; Opdam, F.J.; de Leeuw, H.J.; Jollivet, F.; Savelkoul, P.; Hendriks, W.; Voorberg, J.; Goud, B.; Fransen, J.A. Alternative splicing of the human Rab6A gene generates two close but functionally different isoforms. Mol. Biol. Cell 2000, 11, 3819-3833. [CrossRef]

82. Mallard, F.; Antony, C.; Tenza, D.; Salamero, J.; Goud, B.; Johannes, L. Direct pathway from early/recycling endosomes to the Golgi apparatus revealed through the study of shiga toxin B-fragment transport. J. Cell Biol. 1998, 143, 973-990. [CrossRef]

83. Utskarpen, A.; Slagsvold, H.H.; Iversen, T.-G.; Wälchli, S.; Sandvig, K. Transport of ricin from endosomes to the Golgi apparatus is regulated by Rab6A and Rab6A'. Traffic 2006, 7, 663-672. [CrossRef]

84. Grimmer, S.; Iversen, T.-G.; van Deurs, B.; Sandvig, K. Endosome to Golgi Transport of Ricin Is Regulated by Cholesterol. Mol. Biol. Cell 2000, 11, 4205-4216. [CrossRef] [PubMed] 
85. Lauvrak, S.U.; Llorente, A.; Iversen, T.-G.; Sandvig, K. Selective regulation of the Rab9-independent transport of ricin to the Golgi apparatus by calcium. J. Cell Sci. 2002, 115, 3449-3456. [PubMed]

86. Porat, A.; Elazar, Z. Regulation of intra-Golgi membrane transport by calcium. J. Biol. Chem. 2000, 275, 29233-29237. [CrossRef] [PubMed]

87. Moreau, D.; Kumar, P.; Wang, S.C.; Chaumet, A.; Chew, S.Y.; Chevalley, H.; Bard, F. Genome-wide RNAi screens identify genes required for Ricin and PE intoxications. Dev. Cell 2011, 21, 231-244. [CrossRef] [PubMed]

88. Becker, B.; Schmitt, M.J. A Simple Fluorescence-based Reporter Assay to Identify Cellular Components Required for Ricin Toxin A Chain (RTA) Trafficking in Yeast. J. Vis. Exp. 2017, 130, e56588. [CrossRef] [PubMed]

89. Birkeli, K.A.; Llorente, A.; Torgersen, M.L.; Keryer, G.; Taskén, K.; Sandvig, K. Endosome-to-Golgi transport is regulated by protein kinase A type II alpha. J. Biol. Chem. 2003, 278, 1991-1997. [CrossRef] [PubMed]

90. Skånland, S.S.; Wälchli, S.; Utskarpen, A.; Wandinger-Ness, A.; Sandvig, K. Phosphoinositide-regulated retrograde transport of ricin: Crosstalk between hVps34 and sorting nexins. Traffic 2007, 8, 297-309. [CrossRef]

91. Sandvig, K.; van Deurs, B. Entry of ricin and Shiga toxin into cells: Molecular mechanisms and medical perspectives. EMBO J. 2000, 19, 5943-5950. [CrossRef]

92. Day, P.J.; Owens, S.R.; Wesche, J.; Olsnes, S.; Roberts, L.M.; Lord, J.M. An interaction between ricin and calreticulin that may have implications for toxin trafficking. J. Biol. Chem. 2001, 276, 7202-7208. [CrossRef]

93. Spooner, R.A.; Smith, D.C.; Easton, A.J.; Roberts, L.M.; Lord, J.M. Retrograde transport pathways utilised by viruses and protein toxins. Virol. J. 2006, 3, 26. [CrossRef]

94. Chen, A.; AbuJarour, R.J.; Draper, R.K. Evidence that the transport of ricin to the cytoplasm is independent of both Rab6A and COPI. J. Cell Sci. 2003, 116, 3503-3510. [CrossRef] [PubMed]

95. Llorente, A.; Lauvrak, S.U.; van Deurs, B.; Sandvig, K. Induction of direct endosome to endoplasmic reticulum transport in Chinese hamster ovary $(\mathrm{CHO})$ cells $(\mathrm{LdlF})$ with a temperature-sensitive defect in epsilon-coatomer protein (epsilon-COP). J. Biol. Chem. 2003, 278, 35850-35855. [CrossRef] [PubMed]

96. Otte, S.; Belden, W.J.; Heidtman, M.; Liu, J.; Jensen, O.N.; Barlowe, C. Erv41p and Erv46p: New components of COPII vesicles involved in transport between the ER and Golgi complex. J. Cell Biol. 2001, 152, 503-518. [CrossRef] [PubMed]

97. Adolf, F.; Rhiel, M.; Hessling, B.; Gao, Q.; Hellwig, A.; Béthune, J.; Wieland, F.T. Proteomic Profiling of Mammalian COPII and COPI Vesicles. Cell Rep. 2019, 26, 250-265. [CrossRef]

98. Sato, K.; Sato, M.; Nakano, A. Rer1p, a Retrieval Receptor for Endoplasmic Reticulum Membrane Proteins, Is Dynamically Localized to the Golgi Apparatus by Coatomer. J. Cell Biol. 2001, 152, 935-944. [CrossRef] [PubMed]

99. Liu, Y.; Flanagan, J.J.; Barlowe, C. Sec22p export from the endoplasmic reticulum is independent of SNARE pairing. J. Biol. Chem. 2004, 279, 27225-27232. [CrossRef]

100. Taubenschmid, J.; Stadlmann, J.; Jost, M.; Klokk, T.I.; Rillahan, C.D.; Leibbrandt, A.; Mechtler, K.; Paulson, J.C.; Jude, J.; Zuber, J.; et al. A vital sugar code for ricin toxicity. Cell Res. 2017, 27, 1351-1364. [CrossRef] [PubMed]

101. Simpson, J.C.; Roberts, L.M.; Römisch, K.; Davey, J.; Wolf, D.H.; Lord, J.M. Ricin A chain utilises the endoplasmic reticulum-associated protein degradation pathway to enter the cytosol of yeast. FEBS Lett. 1999, 459, 80-84. [CrossRef]

102. Parikh, B.A.; Tortora, A.; Li, X.-P.; Tumer, N.E. Ricin inhibits activation of the unfolded protein response by preventing splicing of the HAC1 mRNA. J. Biol. Chem. 2008, 283, 6145-6153. [CrossRef]

103. Spooner, R.A.; Watson, P.D.; Marsden, C.J.; Smith, D.C.; Moore, K.A.H.; Cook, J.P.; Lord, J.M.; Roberts, L.M. Protein disulphide-isomerase reduces ricin to its $\mathrm{A}$ and $\mathrm{B}$ chains in the endoplasmic reticulum. Biochem. J. 2004, 383, 285-293. [CrossRef]

104. Redmann, V.; Oresic, K.; Tortorella, L.L.; Cook, J.P.; Lord, M.; Tortorella, D. Dislocation of Ricin Toxin A Chains in Human Cells Utilizes Selective Cellular Factors. J. Biol. Chem. 2011, 286, 21231-21238. [CrossRef]

105. Di Cola, A.; Frigerio, L.; Lord, J.M.; Ceriotti, A.; Roberts, L.M. Ricin A chain without its partner B chain is degraded after retrotranslocation from the endoplasmic reticulum to the cytosol in plant cells. Proc. Natl. Acad. Sci. USA 2001, 98, 14726-14731. [CrossRef] [PubMed]

106. Gemmill, T.R.; Trimble, R.B. Overview of N- and O-linked oligosaccharide structures found in various yeast species. Biochim. Biophys. Acta Gen. Subj. 1999, 1426, 227-237. [CrossRef] 
107. Lamb, F.I.; Roberts, L.M.; Lord, J.M. Nucleotide sequence of cloned cDNA coding for preproricin. Eur. J. Biochem. 1985, 148, 265-270. [CrossRef] [PubMed]

108. Wesche, J.; Rapak, A.; Olsnes, S. Dependence of ricin toxicity on translocation of the toxin A-chain from the endoplasmic reticulum to the cytosol. J. Biol. Chem. 1999, 274, 34443-34449. [CrossRef]

109. Spooner, R.A.; Lord, J.M. How ricin and Shiga toxin reach the cytosol of target cells: Retrotranslocation from the endoplasmic reticulum. Curr. Top. Microbiol. Immunol. 2012, 357, 19-40.

110. Nowakowska-Gołacka, J.; Sominka, H.; Sowa-Rogozińska, N.; Słomińska-Wojewódzka, M. Toxins Utilize the Endoplasmic Reticulum-Associated Protein Degradation Pathway in Their Intoxication Process. Int. J. Mol. Sci. 2019, 20, 1307. [CrossRef]

111. Mohanraj, D.; Ramakrishnan, S. Cytotoxic effects of ricin without an interchain disulfide bond: Genetic modification and chemical crosslinking studies. Biochim. Biophys. Acta Gen. Subj. 1995, 1243, 399-406. [CrossRef]

112. Freedman, R.B.; Hirst, T.R.; Tuite, M.F. Protein disulphide isomerase: Building bridges in protein folding. Trends Biochem. Sci. 1994, 19, 331-336. [CrossRef]

113. Bulleid, N.J. Disulfide Bond Formation in the Mammalian Endoplasmic Reticulum. Cold Spring Harb. Perspect. Biol. 2012, 4, a013219. [CrossRef]

114. Bellisola, G.; Fracasso, G.; Ippoliti, R.; Menestrina, G.; Rosén, A.; Soldà, S.; Udali, S.; Tomazzolli, R.; Tridente, G.; Colombatti, M. Reductive activation of ricin and ricin A-chain immunotoxins by protein disulfide isomerase and thioredoxin reductase. Biochem. Pharmacol. 2004, 67, 1721-1731. [CrossRef] [PubMed]

115. Arnér, E.S.; Holmgren, A. Physiological functions of thioredoxin and thioredoxin reductase. Eur. J. Biochem. 2000, 267, 6102-6109. [CrossRef] [PubMed]

116. Holmgren, A. Antioxidant function of thioredoxin and glutaredoxin systems. Antioxid. Redox Signal. 2000, 2, 811-820. [CrossRef] [PubMed]

117. Richardson, P.T.; Westby, M.; Roberts, L.M.; Gould, J.H.; Colman, A.; Lord, J.M. Recombinant proricin binds galactose but does not depurinate $28 \mathrm{~S}$ ribosomal RNA. FEBS Lett. 1989, 255, 15-20. [CrossRef]

118. Pasetto, M.; Barison, E.; Castagna, M.; Della Cristina, P.; Anselmi, C.; Colombatti, M. Reductive activation of type 2 ribosome-inactivating proteins is promoted by transmembrane thioredoxin-related protein. J. Biol. Chem. 2012, 287, 7367-7373. [CrossRef]

119. Argent, R.H.; Roberts, L.M.; Wales, R.; Robertus, J.D.; Lord, J.M. Introduction of a disulfide bond into ricin A chain decreases the cytotoxicity of the ricin holotoxin. J. Biol. Chem. 1994, 269, 26705-26710.

120. Argent, R.H.; Parrott, A.M.; Day, P.J.; Roberts, L.M.; Stockley, P.G.; Lord, J.M.; Radford, S.E. Ribosome-mediated folding of partially unfolded ricin A-chain. J. Biol. Chem. 2000, 275, 9263-9269. [CrossRef]

121. Ellgaard, L.; Helenius, A. Quality control in the endoplasmic reticulum. Nat. Rev. Mol. Cell Biol. 2003, 4, 181-191. [CrossRef]

122. Hebert, D.N.; Molinari, M. In and out of the ER: Protein folding, quality control, degradation, and related human diseases. Physiol. Rev. 2007, 87, 1377-1408. [CrossRef]

123. Braakman, I.; Hebert, D.N. Protein Folding in the Endoplasmic Reticulum. Cold Spring Harb. Perspect. Biol. 2013, 5, a013201. [CrossRef]

124. Karagöz, G.E.; Acosta-Alvear, D.; Walter, P. The Unfolded Protein Response: Detecting and Responding to Fluctuations in the Protein-Folding Capacity of the Endoplasmic Reticulum. Cold Spring Harb. Perspect. Biol. 2019, a033886. [CrossRef] [PubMed]

125. Tsai, B.; Ye, Y.; Rapoport, T.A. Retro-translocation of proteins from the endoplasmic reticulum into the cytosol. Nat. Rev. Mol. Cell Biol. 2002, 3, 246-255. [CrossRef] [PubMed]

126. Gregers, T.F.; Skånland, S.S.; Wälchli, S.; Bakke, O.; Sandvig, K. BiP negatively affects ricin transport. Toxins 2013, 5, 969-982. [CrossRef] [PubMed]

127. Sun, M.; Kotler, J.L.M.; Liu, S.; Street, T.O. The ER chaperones BiP and Grp94 selectively associate when BiP is in the ADP conformation. J. Biol. Chem. 2019. [CrossRef] [PubMed]

128. Spooner, R.A.; Hart, P.J.; Cook, J.P.; Pietroni, P.; Rogon, C.; Höhfeld, J.; Roberts, L.M.; Lord, J.M. Cytosolic chaperones influence the fate of a toxin dislocated from the endoplasmic reticulum. Proc. Natl. Acad. Sci. USA 2008, 105, 17408-17413. [CrossRef] [PubMed] 
129. Pearse, B.R.; Hebert, D.N. Lectin chaperones help direct the maturation of glycoproteins in the endoplasmic reticulum. Biochim. Biophys. Acta Mol. Cell Res. 2010, 1803, 684-693. [CrossRef]

130. Kapoor, M.; Srinivas, H.; Kandiah, E.; Gemma, E.; Ellgaard, L.; Oscarson, S.; Helenius, A.; Surolia, A. Interactions of Substrate with Calreticulin, an Endoplasmic Reticulum Chaperone. J. Biol. Chem. 2003, 278, 6194-6200. [CrossRef]

131. Hosokawa, N.; Wada, I.; Hasegawa, K.; Yorihuzi, T.; Tremblay, L.O.; Herscovics, A.; Nagata, K. A novel ER alpha-mannosidase-like protein accelerates ER-associated degradation. EMBO Rep. 2001, 2, 415-422. [CrossRef]

132. Mast, S.W.; Diekman, K.; Karaveg, K.; Davis, A.; Sifers, R.N.; Moremen, K.W. Human EDEM2, a novel homolog of family 47 glycosidases, is involved in ER-associated degradation of glycoproteins. Glycobiology 2005, 15, 421-436. [CrossRef]

133. Hirao, K.; Natsuka, Y.; Tamura, T.; Wada, I.; Morito, D.; Natsuka, S.; Romero, P.; Sleno, B.; Tremblay, L.O.; Herscovics, A.; et al. EDEM3, a soluble EDEM homolog, enhances glycoprotein endoplasmic reticulum-associated degradation and mannose trimming. J. Biol. Chem. 2006, 281, 9650-9658. [CrossRef]

134. Olivari, S.; Molinari, M. Glycoprotein folding and the role of EDEM1, EDEM2 and EDEM3 in degradation of folding-defective glycoproteins. FEBS Lett. 2007, 581, 3658-3664. [CrossRef] [PubMed]

135. Slominska-Wojewodzka, M.; Gregers, T.F.; Wälchli, S.; Sandvig, K. EDEM Is Involved in Retrotranslocation of Ricin from the Endoplasmic Reticulum to the Cytosol. Mol. Biol. Cell 2006, 17, 1664-1675. [CrossRef] [PubMed]

136. Słomińska-Wojewódzka, M.; Pawlik, A.; Sokołowska, I.; Antoniewicz, J.; Węgrzyn, G.; Sandvig, K. The role of EDEM2 compared with EDEM1 in ricin transport from the endoplasmic reticulum to the cytosol. Biochem. J. 2014, 457, 485-496. [CrossRef] [PubMed]

137. Słomińska-Wojewódzka, M.; Sandvig, K. The Role of Lectin-Carbohydrate Interactions in the Regulation of ER-Associated Protein Degradation. Molecules 2015, 20, 9816-9846. [CrossRef] [PubMed]

138. Sominka, H.; Nowakowska-Gołacka, J.; Sowa-Rogozińska, N.; Słomińska-Wojewódzka, M. The role of EDEM3 in ricin cytotoxicity and its transport from the ER to the cytosol. Unpublished. Manuscript in preparation.

139. Mayerhofer, P.U.; Cook, J.P.; Wahlman, J.; Pinheiro, T.T.J.; Moore, K.A.H.; Lord, J.M.; Johnson, A.E.; Roberts, L.M. Ricin A Chain Insertion into Endoplasmic Reticulum Membranes Is Triggered by a Temperature Increase to $37^{\circ} \mathrm{C}$. J. Biol. Chem. 2009, 284, 10232-10242. [CrossRef] [PubMed]

140. Katzin, B.J.; Collins, E.J.; Robertus, J.D. Structure of ricin A-chain at 2.5 A. Proteins 1991, 10, $251-259$. [CrossRef] [PubMed]

141. Yan, Q.; Li, X.-P.; Tumer, N.E. N-glycosylation does not affect the catalytic activity of ricin a chain but stimulates cytotoxicity by promoting its transport out of the endoplasmic reticulum. Traffic 2012, 13, 1508-1521. [CrossRef] [PubMed]

142. Leto, D.E.; Morgens, D.W.; Zhang, L.; Walczak, C.P.; Elias, J.E.; Bassik, M.C.; Kopito, R.R. Genome-wide CRISPR Analysis Identifies Substrate-Specific Conjugation Modules in ER-Associated Degradation. Mol. Cell 2019, 73, 377-389. [CrossRef]

143. Pilon, M.; Schekman, R.; Römisch, K. Sec61p mediates export of a misfolded secretory protein from the endoplasmic reticulum to the cytosol for degradation. EMBO J. 1997, 16, 4540-4548. [CrossRef]

144. Schäfer, A.; Wolf, D.H. Sec61p is part of the endoplasmic reticulum-associated degradation machinery. EMBO J. 2009, 28, 2874-2884. [CrossRef]

145. Tretter, T.; Pereira, F.P.; Ulucan, O.; Helms, V.; Allan, S.; Kalies, K.-U.; Römisch, K. ERAD and protein import defects in a sec61 mutant lacking ER-lumenal loop 7. BMC Cell Biol. 2013, 14, 56. [CrossRef] [PubMed]

146. Kaiser, M.-L.; Römisch, K. Proteasome 19S RP Binding to the Sec61 Channel Plays a Key Role in ERAD. PLoS ONE 2015, 10, e0117260. [CrossRef] [PubMed]

147. Römisch, K. A Case for Sec61 Channel Involvement in ERAD. Trends Biochem. Sci. 2017, 42, 171-179. [CrossRef] [PubMed]

148. Lilley, B.N.; Ploegh, H.L. A membrane protein required for dislocation of misfolded proteins from the ER. Nature 2004, 429, 834-840. [CrossRef] [PubMed]

149. Ye, Y.; Shibata, Y.; Yun, C.; Ron, D.; Rapoport, T.A. A membrane protein complex mediates retro-translocation from the ER lumen into the cytosol. Nature 2004, 429, 841-847. [CrossRef] [PubMed] 
150. Lilley, B.N.; Ploegh, H.L. Multiprotein complexes that link dislocation, ubiquitination, and extraction of misfolded proteins from the endoplasmic reticulum membrane. Proc. Natl. Acad. Sci. USA 2005, 102, 14296-14301. [CrossRef] [PubMed]

151. Oda, Y.; Okada, T.; Yoshida, H.; Kaufman, R.J.; Nagata, K.; Mori, K. Derlin-2 and Derlin-3 are regulated by the mammalian unfolded protein response and are required for ER-associated degradation. J. Cell Biol. 2006, 172, 383-393. [CrossRef]

152. You, H.; Ge, Y.; Zhang, J.; Cao, Y.; Xing, J.; Su, D.; Huang, Y.; Li, M.; Qu, S.; Sun, F.; et al. Derlin-1 promotes ubiquitylation and degradation of the epithelial $\mathrm{Na}+$ channel, ENaC. J. Cell Sci. 2017, 130, 1027-1036.

153. Mehnert, M.; Sommer, T.; Jarosch, E. Der1 promotes movement of misfolded proteins through the endoplasmic reticulum membrane. Nat. Cell Biol. 2014, 16, 77-86. [CrossRef]

154. Kikkert, M.; Doolman, R.; Dai, M.; Avner, R.; Hassink, G.; van Voorden, S.; Thanedar, S.; Roitelman, J.; Chau, V.; Wiertz, E. Human HRD1 is an E3 ubiquitin ligase involved in degradation of proteins from the endoplasmic reticulum. J. Biol. Chem. 2004, 279, 3525-3534. [CrossRef]

155. Carvalho, P.; Stanley, A.M.; Rapoport, T.A. Retrotranslocation of a misfolded luminal ER protein by the ubiquitin-ligase Hrd1p. Cell 2010, 143, 579-591. [CrossRef]

156. Stein, A.; Ruggiano, A.; Carvalho, P.; Rapoport, T.A. Key steps in ERAD of luminal ER proteins reconstituted with purified components. Cell 2014, 158, 1375-1388. [CrossRef] [PubMed]

157. Baldridge, R.D.; Rapoport, T.A. Autoubiquitination of the Hrd1 Ligase Triggers Protein Retrotranslocation in ERAD. Cell 2016, 166, 394-407. [CrossRef] [PubMed]

158. Schoebel, S.; Mi, W.; Stein, A.; Ovchinnikov, S.; Pavlovicz, R.; DiMaio, F.; Baker, D.; Chambers, M.G.; Su, H.; Li, D.; et al. Cryo-EM structure of the protein-conducting ERAD channel Hrd1 in complex with Hrd3. Nature 2017, 548, 352-355. [CrossRef] [PubMed]

159. Hwang, J.; Qi, L. Quality Control in the Endoplasmic Reticulum: Crosstalk between ERAD and UPR pathways. Trends Biochem. Sci. 2018, 43, 593-605. [CrossRef]

160. Zheng, N.; Shabek, N. Ubiquitin Ligases: Structure, Function, and Regulation. Annu. Rev. Biochem. 2017, 86, 129-157. [CrossRef]

161. Sowa-Rogozińska, N.; Słomińska-Wojewódzka, M. The role of Sec61 in ricin transport from the ER to the cytosol. Unpublished. Manuscript in preparation.

162. Sowa-Rogozińska, N.; Sominka, H.; Słomińska-Wojewódzka, M. The role of Derlin proteins in ricin transport from the ER to the cytosol. Unpublished. Manuscript in preparation.

163. Dang, H.; Klokk, T.I.; Schaheen, B.; McLaughlin, B.M.; Thomas, A.J.; Durns, T.A.; Bitler, B.G.; Sandvig, K.; Fares, H. Derlin-dependent retrograde transport from endosomes to the Golgi apparatus. Traffic 2011, 12, 1417-1431. [CrossRef] [PubMed]

164. Li, S.; Spooner, R.A.; Allen, S.C.H.; Guise, C.P.; Ladds, G.; Schnöder, T.; Schmitt, M.J.; Lord, J.M.; Roberts, L.M. Folding-competent and folding-defective forms of ricin A chain have different fates after retrotranslocation from the endoplasmic reticulum. Mol. Biol. Cell 2010, 21, 2543-2554. [CrossRef] [PubMed]

165. Eshraghi, A.; Dixon, S.D.; Tamilselvam, B.; Kim, E.J.-K.; Gargi, A.; Kulik, J.C.; Damoiseaux, R.; Blanke, S.R.; Bradley, K.A. Cytolethal distending toxins require components of the ER-associated degradation pathway for host cell entry. PLoS Pathog. 2014, 10, e1004295. [CrossRef]

166. Pietroni, P.; Vasisht, N.; Cook, J.P.; Roberts, D.M.; Lord, J.M.; Hartmann-Petersen, R.; Roberts, L.M.; Spooner, R.A. The proteasome cap RPT5/Rpt5p subunit prevents aggregation of unfolded ricin A chain. Biochem. J. 2013, 453, 435-445. [CrossRef]

167. Di Cola, A.; Frigerio, L.; Lord, J.M.; Roberts, L.M.; Ceriotti, A. Endoplasmic Reticulum-Associated Degradation of Ricin A Chain Has Unique and Plant-Specific Features. Plant Physiol. 2005, 137, 287-296. [CrossRef]

168. Deeks, E.D.; Cook, J.P.; Day, P.J.; Smith, D.C.; Roberts, L.M.; Lord, J.M. The low lysine content of ricin A chain reduces the risk of proteolytic degradation after translocation from the endoplasmic reticulum to the cytosol. Biochemistry 2002, 41, 3405-3413. [CrossRef] [PubMed]

169. Abujarour, R.J.; Dalal, S.; Hanson, P.I.; Draper, R.K. p97 Is in a complex with cholera toxin and influences the transport of cholera toxin and related toxins to the cytoplasm. J. Biol. Chem. 2005, 280, 15865-15871. [CrossRef] [PubMed]

170. Thrower, J.S.; Hoffman, L.; Rechsteiner, M.; Pickart, C.M. Recognition of the polyubiquitin proteolytic signal. EMBO J. 2000, 19, 94-102. [CrossRef] [PubMed] 
171. Rodighiero, C.; Tsai, B.; Rapoport, T.A.; Lencer, W.I. Role of ubiquitination in retro-translocation of cholera toxin and escape of cytosolic degradation. EMBO Rep. 2002, 3, 1222-1227. [CrossRef] [PubMed]

172. Lipson, C.; Alalouf, G.; Bajorek, M.; Rabinovich, E.; Atir-Lande, A.; Glickman, M.; Bar-Nun, S. A proteasomal ATPase contributes to dislocation of endoplasmic reticulum-associated degradation (ERAD) substrates. J. Biol. Chem. 2008, 283, 7166-7175. [CrossRef] [PubMed]

173. Odunuga, O.O.; Longshaw, V.M.; Blatch, G.L. Hop: More than an Hsp70/Hsp90 adaptor protein. Bioessays 2004, 26, 1058-1068. [CrossRef] [PubMed]

174. Li, X.-P.; Grela, P.; Krokowski, D.; Tchórzewski, M.; Tumer, N.E. Pentameric organization of the ribosomal stalk accelerates recruitment of ricin a chain to the ribosome for depurination. J. Biol. Chem. 2010, 285, 41463-41471. [CrossRef] [PubMed]

175. Larsson, S.L.; Sloma, M.S.; Nygård, O. Conformational changes in the structure of domains II and V of $28 \mathrm{~S}$ rRNA in ribosomes treated with the translational inhibitors ricin or alpha-sarcin. Biochim. Biophys. Acta 2002, 1577, 53-62. [CrossRef]

176. Endo, Y.; Tsurugi, K. The RNA N-glycosidase activity of ricin A-chain. The characteristics of the enzymatic activity of ricin A-chain with ribosomes and with rRNA. J. Biol. Chem. 1988, 263, 8735-8739.

177. May, K.L.; Yan, Q.; Tumer, N.E. Targeting ricin to the ribosome. Toxicon 2013, 69, 143-151. [CrossRef] [PubMed]

178. Chiou, J.-C.; Li, X.-P.; Remacha, M.; Ballesta, J.P.G.; Tumer, N.E. The ribosomal stalk is required for ribosome binding, depurination of the rRNA and cytotoxicity of ricin A chain in Saccharomyces cerevisiae. Mol. Microbiol. 2008, 70, 1441-1452. [CrossRef] [PubMed]

179. May, K.L.; Li, X.-P.; Martínez-Azorín, F.; Ballesta, J.P.G.; Grela, P.; Tchórzewski, M.; Tumer, N.E. The P1/P2 proteins of the human ribosomal stalk are required for ribosome binding and depurination by ricin in human cells. FEBS J. 2012, 279, 3925-3936. [CrossRef] [PubMed]

180. Grela, P.; Sawa-Makarska, J.; Gordiyenko, Y.; Robinson, C.V.; Grankowski, N.; Tchórzewski, M. Structural properties of the human acidic ribosomal P proteins forming the P1-P2 heterocomplex. J. Biochem. 2008, 143, 169-177. [CrossRef] [PubMed]

181. Lee, K.-M.; Yu, C.W.-H.; Chiu, T.Y.-H.; Sze, K.-H.; Shaw, P.-C.; Wong, K.-B. Solution structure of the dimerization domain of the eukaryotic stalk P1/P2 complex reveals the structural organization of eukaryotic stalk complex. Nucleic Acids Res. 2012, 40, 3172-3182. [CrossRef] [PubMed]

182. Grela, P.; Li, X.-P.; Horbowicz, P.; Dźwierzyńska, M.; Tchórzewski, M.; Tumer, N.E. Human ribosomal P1-P2 heterodimer represents an optimal docking site for ricin A chain with a prominent role for P1 C-terminus. Sci. Rep. 2017, 7, 5608. [CrossRef] [PubMed]

183. Grela, P.; Li, X.-P.; Tchórzewski, M.; Tumer, N.E. Functional divergence between the two P1-P2 stalk dimers on the ribosome in their interaction with ricin A chain. Biochem. J. 2014, 460, 59-67. [CrossRef]

184. Grela, P.; Bernadó, P.; Svergun, D.; Kwiatowski, J.; Abramczyk, D.; Grankowski, N.; Tchórzewski, M. Structural relationships among the ribosomal stalk proteins from the three domains of life. J. Mol. Evol. 2008, 67, 154-167. [CrossRef] [PubMed]

185. Li, X.-P.; Chiou, J.-C.; Remacha, M.; Ballesta, J.P.G.; Tumer, N.E. A two-step binding model proposed for the electrostatic interactions of ricin A chain with ribosomes. Biochemistry 2009, 48, 3853-3863. [CrossRef] [PubMed]

186. Tumer, N.E.; Li, X.-P. Interaction of ricin and Shiga toxins with ribosomes. Curr. Top. Microbiol. Immunol. 2012, 357, 1-18.

187. Fan, X.; Zhu, Y.; Wang, C.; Niu, L.; Teng, M.; Li, X. Structural insights into the interaction of the ribosomal P stalk protein P2 with a type II ribosome-inactivating protein ricin. Sci. Rep. 2016, 6, 37803. [CrossRef] [PubMed]

188. Shi, W.-W.; Tang, Y.-S.; Sze, S.-Y.; Zhu, Z.-N.; Wong, K.-B.; Shaw, P.-C. Crystal Structure of Ribosome-Inactivating Protein Ricin A Chain in Complex with the C-Terminal Peptide of the Ribosomal Stalk Protein P2. Toxins 2016, 8, 296. [CrossRef] [PubMed]

189. Watanabe, K.; Dansako, H.; Asada, N.; Sakai, M.; Funatsu, G. Effects of chemical modification of arginine residues outside the active site cleft of ricin A-chain on its RNA N-glycosidase activity for ribosomes. Biosci. Biotechnol. Biochem. 1994, 58, 716-721. [CrossRef] [PubMed]

190. Marsden, C.J.; Fülöp, V.; Day, P.J.; Lord, J.M. The effect of mutations surrounding and within the active site on the catalytic activity of ricin A chain. Eur. J. Biochem. 2004, 271, 153-162. [CrossRef] [PubMed] 
191. Zhou, Y.; Li, X.-P.; Chen, B.Y.; Tumer, N.E. Ricin uses arginine 235 as an anchor residue to bind to P-proteins of the ribosomal stalk. Sci. Rep. 2017, 7, 42912. [CrossRef] [PubMed]

192. Li, X.-P.; Kahn, P.C.; Kahn, J.N.; Grela, P.; Tumer, N.E. Arginine residues on the opposite side of the active site stimulate the catalysis of ribosome depurination by ricin A chain by interacting with the P-protein stalk. J. Biol. Chem. 2013, 288, 30270-30284. [CrossRef] [PubMed]

193. Li, X.-P.; Tumer, N.E. Differences in Ribosome Binding and Sarcin/Ricin Loop Depurination by Shiga and Ricin Holotoxins. Toxins 2017, 9, 133. [CrossRef] [PubMed]

194. Jetzt, A.E.; Li, X.-P.; Tumer, N.E.; Cohick, W.S. Toxicity of ricin A chain is reduced in mammalian cells by inhibiting its interaction with the ribosome. Toxicol. Appl. Pharmacol. 2016, 310, 120-128. [CrossRef]

195. Hedblom, M.L.; Cawley, D.B.; Boguslawski, S.; Houston, L.L. Binding of ricin A chain to rat liver ribosomes: Relationship to ribosome inactivation. J. Supramol. Struct. 1978, 9, 253-268. [CrossRef]

196. Honjo, E.; Watanabe, K.; Tsukamoto, T. Real-time kinetic analyses of the interaction of ricin toxin A-chain with ribosomes prove a conformational change involved in complex formation. J. Biochem. 2002, 131, 267-275. [CrossRef]

197. Dai, J.; Zhao, L.; Yang, H.; Guo, H.; Fan, K.; Wang, H.; Qian, W.; Zhang, D.; Li, B.; Wang, H.; et al. Identification of a novel functional domain of ricin responsible for its potent toxicity. J. Biol. Chem. 2011, 286, 12166-12171. [CrossRef] [PubMed]

198. Morris, K.N.; Wool, I.G. Determination by systematic deletion of the amino acids essential for catalysis by ricin A chain. Proc. Natl. Acad. Sci. USA 1992, 89, 4869-4873. [CrossRef] [PubMed]

199. Day, P.J.; Ernst, S.R.; Frankel, A.E.; Monzingo, A.F.; Pascal, J.M.; Molina-Svinth, M.C.; Robertus, J.D. Structure and activity of an active site substitution of ricin A chain. Biochemistry 1996, 35, 11098-11103. [CrossRef] [PubMed]

200. Li, X.-P.; Kahn, J.N.; Tumer, N.E. Peptide Mimics of the Ribosomal P Stalk Inhibit the Activity of Ricin A Chain by Preventing Ribosome Binding. Toxins 2018, 10, 371. [CrossRef]

201. Lewis, J.L.; Shields, K.A.; Chong, D.C. Detection and quantification of ricin-mediated $28 \mathrm{~S}$ ribosomal depurination by digital droplet PCR. Anal. Biochem. 2018, 563, 15-19. [CrossRef]

202. Falach, R.; Sapoznikov, A.; Gal, Y.; Israeli, O.; Leitner, M.; Seliger, N.; Ehrlich, S.; Kronman, C.; Sabo, T. Quantitative profiling of the in vivo enzymatic activity of ricin reveals disparate depurination of different pulmonary cell types. Toxicol. Lett. 2016, 258, 11-19. [CrossRef]

203. Meneguelli de Souza, L.C.; de Carvalho, L.P.; Araújo, J.S.; de Melo, E.J.T.; Machado, O.L.T. Cell toxicity by ricin and elucidation of mechanism of Ricin inactivation. Int. J. Biol. Macromol. 2018, 113, 821-828. [CrossRef]

204. Sandvig, K.; van Deurs, B. Toxin-induced cell lysis: Protection by 3-methyladenine and cycloheximide. Exp. Cell Res. 1992, 200, 253-262. [CrossRef]

205. Bagaria, S.; Karande, A. Abrin and Immunoneutralization: A Review. Toxinology 2014. [CrossRef]

206. Bingen, A.; Creppy, E.E.; Gut, J.P.; Dirheimer, G.; Kirn, A. The Kupffer cell is the first target in ricin-induced hepatitis. J. Submicrosc. Cytol. 1987, 19, 247-256.

207. Leek, M.D.; Griffiths, G.D.; Green, M.A. Intestinal pathology following intramuscular ricin poisoning. J. Pathol. 1989, 159, 329-334. [CrossRef] [PubMed]

208. Wilhelmsen, C.L.; Pitt, M.L. Lesions of acute inhaled lethal ricin intoxication in rhesus monkeys. Vet. Pathol. 1996, 33, 296-302. [CrossRef] [PubMed]

209. Soler-Rodríguez, A.M.; Ghetie, M.A.; Oppenheimer-Marks, N.; Uhr, J.W.; Vitetta, E.S. Ricin A-chain and ricin A-chain immunotoxins rapidly damage human endothelial cells: Implications for vascular leak syndrome. Exp. Cell Res. 1993, 206, 227-234. [CrossRef] [PubMed]

210. Kochi, S.K.; Collier, R.J. DNA fragmentation and cytolysis in U937 cells treated with diphtheria toxin or other inhibitors of protein synthesis. Exp. Cell Res. 1993, 208, 296-302. [CrossRef] [PubMed]

211. Peumans, W.J.; Hao, Q.; Van Damme, E.J. Ribosome-inactivating proteins from plants: More than RNA N-glycosidases? FASEB J. 2001, 15, 1493-1506. [CrossRef] [PubMed]

212. Brigotti, M.; Alfieri, R.; Sestili, P.; Bonelli, M.; Petronini, P.G.; Guidarelli, A.; Barbieri, L.; Stirpe, F.; Sperti, S. Damage to nuclear DNA induced by Shiga toxin 1 and ricin in human endothelial cells. FASEB J. 2002, 16, 365-372. [CrossRef] [PubMed]

213. Li, M.; Pestka, J.J. Comparative induction of $28 \mathrm{~S}$ ribosomal RNA cleavage by ricin and the trichothecenes deoxynivalenol and T-2 toxin in the macrophage. Toxicol. Sci. 2008, 105, 67-78. [CrossRef] [PubMed] 
214. Gray, J.S.; Bae, H.K.; Li, J.C.B.; Lau, A.S.; Pestka, J.J. Double-stranded RNA-activated protein kinase mediates induction of interleukin-8 expression by deoxynivalenol, Shiga toxin 1, and ricin in monocytes. Toxicol. Sci. 2008, 105, 322-330. [CrossRef] [PubMed]

215. Tesh, V.L. The induction of apoptosis by Shiga toxins and ricin. Curr. Top. Microbiol. Immunol. 2012, 357, 137-178. [PubMed]

216. Komatsu, N.; Oda, T.; Muramatsu, T. Involvement of both caspase-like proteases and serine proteases in apoptotic cell death induced by ricin, modeccin, diphtheria toxin, and pseudomonas toxin. J. Biochem. 1998, 124, 1038-1044. [CrossRef] [PubMed]

217. Williams, J.M.; Lea, N.; Lord, J.M.; Roberts, L.M.; Milford, D.V.; Taylor, C.M. Comparison of ribosome-inactivating proteins in the induction of apoptosis. Toxicol. Lett. 1997, 91, 121-127. [CrossRef]

218. Rao, P.V.L.; Jayaraj, R.; Bhaskar, A.S.B.; Kumar, O.; Bhattacharya, R.; Saxena, P.; Dash, P.K.; Vijayaraghavan, R. Mechanism of ricin-induced apoptosis in human cervical cancer cells. Biochem. Pharmacol. 2005, 69, 855-865. [CrossRef] [PubMed]

219. Jetzt, A.E.; Cheng, J.-S.; Tumer, N.E.; Cohick, W.S. Ricin A-chain requires c-Jun N-terminal kinase to induce apoptosis in nontransformed epithelial cells. Int. J. Biochem. Cell Biol. 2009, 41, 2503-2510. [CrossRef] [PubMed]

220. Komatsu, N.; Nakagawa, M.; Oda, T.; Muramatsu, T. Depletion of intracellular NAD(+) and ATP levels during ricin-induced apoptosis through the specific ribosomal inactivation results in the cytolysis of U937 cells. J. Biochem. 2000, 128, 463-470. [CrossRef] [PubMed]

221. Wu, Y.-H.; Shih, S.-F.; Lin, J.-Y. Ricin Triggers Apoptotic Morphological Changes through Caspase-3 Cleavage of BAT3. J. Biol. Chem. 2004, 279, 19264-19275. [CrossRef] [PubMed]

222. Sha, O.; Yew, D.T.W.; Ng, T.B.; Yuan, L.; Kwong, W.H. Different in vitro toxicities of structurally similar type I ribosome-inactivating proteins (RIPs). Toxicol. In Vitro 2010, 24, 1176-1182. [CrossRef] [PubMed]

223. Brinkmann, U.; Mansfield, E.; Pastan, I. Effects of BCL-2 overexpression on the sensitivity of MCF-7 breast cancer cells to ricin, diphtheria and Pseudomonas toxin and immunotoxins. Apoptosis 1997, 2, 192-198. [CrossRef] [PubMed]

224. Hu, R.; Zhai, Q.; Liu, W.; Liu, X. An insight into the mechanism of cytotoxicity of ricin to hepatoma cell: Roles of Bcl-2 family proteins, caspases, $\mathrm{Ca}(2+)$-dependent proteases and protein kinase C. J. Cell. Biochem. 2001, 81, 583-593. [CrossRef] [PubMed]

225. Tamura, T.; Oda, T.; Muramatsu, T. Resistance against ricin-induced apoptosis in a brefeldin A-resistant mutant cell line (BER-40) of Vero cells. J. Biochem. 2002, 132, 441-449. [CrossRef] [PubMed]

226. Iordanov, M.S.; Pribnow, D.; Magun, J.L.; Dinh, T.H.; Pearson, J.A.; Chen, S.L.; Magun, B.E. Ribotoxic stress response: Activation of the stress-activated protein kinase JNK1 by inhibitors of the peptidyl transferase reaction and by sequence-specific RNA damage to the alpha-sarcin/ricin loop in the 28S rRNA. Mol. Cell Biol. 1997, 17, 3373-3381. [CrossRef]

227. Korcheva, V.; Wong, J.; Corless, C.; Iordanov, M.; Magun, B. Administration of ricin induces a severe inflammatory response via nonredundant stimulation of ERK, JNK, and P38 MAPK and provides a mouse model of hemolytic uremic syndrome. Am. J. Pathol. 2005, 166, 323-339. [CrossRef]

228. Gonzalez, T.V.; Farrant, S.A.; Mantis, N.J. Ricin induces IL-8 secretion from human monocyte/macrophages by activating the p38 MAP kinase pathway. Mol. Immunol. 2006, 43, 1920-1923. [CrossRef] [PubMed]

229. Korcheva, V.; Wong, J.; Lindauer, M.; Jacoby, D.B.; Iordanov, M.S.; Magun, B. Role of Apoptotic Signaling Pathways in Regulation of Inflammatory Responses to Ricin in Primary Murine Macrophages. Mol. Immunol. 2007, 44, 2761-2771. [CrossRef] [PubMed]

230. Wong, J.; Korcheva, V.; Jacoby, D.B.; Magun, B.E. Proinflammatory responses of human airway cells to ricin involve stress-activated protein kinases and NF-kappaB. Am. J. Physiol. Lung Cell. Mol. Physiol. 2007, 293, L1385-L1394. [CrossRef] [PubMed]

231. Yamasaki, C.; Nishikawa, K.; Zeng, X.-T.; Katayama, Y.; Natori, Y.; Komatsu, N.; Oda, T.; Natori, Y. Induction of cytokines by toxins that have an identical RNA N-glycosidase activity: Shiga toxin, ricin, and modeccin. Biochim. Biophys. Acta 2004, 1671, 44-50. [CrossRef] [PubMed]

232. Lindauer, M.L.; Wong, J.; Iwakura, Y.; Magun, B.E. Pulmonary inflammation triggered by ricin toxin requires macrophages and IL-1 signaling. J. Immunol. 2009, 183, 1419-1426. [CrossRef] [PubMed]

233. Lindauer, M.; Wong, J.; Magun, B. Ricin Toxin Activates the NALP3 Inflammasome. Toxins 2010, 2, 1500-1514. [CrossRef] 
234. Gal, Y.; Mazor, O.; Falach, R.; Sapoznikov, A.; Kronman, C.; Sabo, T. Treatments for Pulmonary Ricin Intoxication: Current Aspects and Future Prospects. Toxins 2017, 9, 311. [CrossRef]

235. Jandhyala, D.M.; Ahluwalia, A.; Obrig, T.; Thorpe, C.M. ZAK: A MAP3Kinase that transduces Shiga toxinand ricin-induced proinflammatory cytokine expression. Cell. Microbiol. 2008, 10, 1468-1477. [CrossRef]

236. Higuchi, S.; Tamura, T.; Oda, T. Cross-talk between the pathways leading to the induction of apoptosis and the secretion of tumor necrosis factor-alpha in ricin-treated RAW 264.7 cells. J. Biochem. 2003, 134, 927-933. [CrossRef]

237. Wang, C.-T.; Jetzt, A.E.; Cheng, J.-S.; Cohick, W.S. Inhibition of the Unfolded Protein Response by Ricin A-Chain Enhances Its Cytotoxicity in Mammalian Cells. Toxins 2011, 3, 453-468. [CrossRef] [PubMed]

238. Horrix, C.; Raviv, Z.; Flescher, E.; Voss, C.; Berger, M.R. Plant ribosome-inactivating proteins type II induce the unfolded protein response in human cancer cells. Cell. Mol. Life Sci. 2011, 68, 1269-1281. [CrossRef] [PubMed]

239. Barbieri, L.; Brigotti, M.; Perocco, P.; Carnicelli, D.; Ciani, M.; Mercatali, L.; Stirpe, F. Ribosome-inactivating proteins depurinate poly(ADP-ribosyl) ated poly(ADP-ribose) polymerase and have transforming activity for 3 T3 fibroblasts. FEBS Lett. 2003, 538, 178-182. [CrossRef]

240. Oda, T.; Iwaoka, J.; Komatsu, N.; Muramatsu, T. Involvement of N-acetylcysteine-sensitive pathways in ricin-induced apoptotic cell death in U937 cells. Biosci. Biotechnol. Biochem. 1999, 63, 341-348. [CrossRef] [PubMed]

241. Oda, T.; Komatsu, N.; Muramatsu, T. Inhibitory effect of dideoxyforskolin on cell death induced by ricin, modeccin, diphtheria toxin, and Pseudomonas toxin in MDCK cells. Cell Struct. Funct. 1997, 22, 545-554. [CrossRef] [PubMed]

242. Tamura, T.; Sadakata, N.; Oda, T.; Muramatsu, T. Role of zinc ions in ricin-induced apoptosis in U937 cells. Toxicol. Lett. 2002, 132, 141-151. [CrossRef]

243. Authier, F.; Djavaheri-Mergny, M.; Lorin, S.; Frénoy, J.-P.; Desbuquois, B. Fate and action of ricin in rat liver in vivo: Translocation of endocytosed ricin into cytosol and induction of intrinsic apoptosis by ricin B-chain. Cell. Microbiol. 2016, 18, 1800-1814. [CrossRef] [PubMed]

244. Elmore, S. Apoptosis: A review of programmed cell death. Toxicol. Pathol. 2007, 35, 495-516. [CrossRef]

245. Nagata, S. Apoptosis and Clearance of Apoptotic Cells. Annu. Rev. Immunol. 2018, 36, 489-517. [CrossRef] [PubMed]

246. Boulares, A.H.; Yakovlev, A.G.; Ivanova, V.; Stoica, B.A.; Wang, G.; Iyer, S.; Smulson, M. Role of poly(ADP-ribose) polymerase (PARP) cleavage in apoptosis. Caspase 3-resistant PARP mutant increases rates of apoptosis in transfected cells. J. Biol. Chem. 1999, 274, 22932-22940. [CrossRef]

247. Kitazumi, I.; Tsukahara, M. Regulation of DNA fragmentation: The role of caspases and phosphorylation. FEBS J. 2011, 278, 427-441. [CrossRef] [PubMed]

248. Desmots, F.; Russell, H.R.; Michel, D.; McKinnon, P.J. Scythe regulates apoptosis-inducing factor stability during endoplasmic reticulum stress-induced apoptosis. J. Biol. Chem. 2008, 283, 3264-3271. [CrossRef] [PubMed]

249. Czabotar, P.E.; Lessene, G.; Strasser, A.; Adams, J.M. Control of apoptosis by the BCL-2 protein family: Implications for physiology and therapy. Nat. Rev. Mol. Cell Biol. 2014, 15, 49-63. [CrossRef]

250. Lin, A.; Minden, A.; Martinetto, H.; Claret, F.X.; Lange-Carter, C.; Mercurio, F.; Johnson, G.L.; Karin, M. Identification of a dual specificity kinase that activates the Jun kinases and p38-Mpk2. Science 1995, 268, 286-290. [CrossRef] [PubMed]

251. Cargnello, M.; Roux, P.P. Activation and function of the MAPKs and their substrates, the MAPK-activated protein kinases. Microbiol. Mol. Biol. Rev. 2011, 75, 50-83. [CrossRef] [PubMed]

252. Liu, H.; Ma, Y.; Pagliari, L.J.; Perlman, H.; Yu, C.; Lin, A.; Pope, R.M. TNF-alpha-induced apoptosis of macrophages following inhibition of NF-kappa B: A central role for disruption of mitochondria. J. Immunol. 2004, 172, 1907-1915. [CrossRef] [PubMed]

253. Papa, S.; Bubici, C.; Zazzeroni, F.; Pham, C.G.; Kuntzen, C.; Knabb, J.R.; Dean, K.; Franzoso, G. The NF-kappaB-mediated control of the JNK cascade in the antagonism of programmed cell death in health and disease. Cell Death Differ. 2006, 13, 712-729. [CrossRef] [PubMed]

254. Bernales, S.; Papa, F.R.; Walter, P. Intracellular signaling by the unfolded protein response. Annu. Rev. Cell Dev. Biol. 2006, 22, 487-508. [CrossRef] 
255. Adams, C.J.; Kopp, M.C.; Larburu, N.; Nowak, P.R.; Ali, M.M.U. Structure and Molecular Mechanism of ER Stress Signaling by the Unfolded Protein Response Signal Activator IRE1. Front. Mol. Biosci. 2019, 6, 11. [CrossRef]

256. Guerra-Moreno, A.; Ang, J.; Welsch, H.; Jochem, M.; Hanna, J. Regulation of the unfolded protein response in yeast by oxidative stress. FEBS Lett. 2019, 593, 1080-1088. [CrossRef]

257. Barbieri, L.; Valbonesi, P.; Bonora, E.; Gorini, P.; Bolognesi, A.; Stirpe, F. Polynucleotide: Adenosine glycosidase activity of ribosome-inactivating proteins: Effect on DNA, RNA and poly(A). Nucleic Acids Res. 1997, 25, 518-522. [CrossRef] [PubMed]

258. D'Amours, D.; Desnoyers, S.; D'Silva, I.; Poirier, G.G. Poly(ADP-ribosyl) ation reactions in the regulation of nuclear functions. Biochem. J. 1999, 342 Pt 2, 249-268. [CrossRef]

259. Sestili, P.; Alfieri, R.; Carnicelli, D.; Martinelli, C.; Barbieri, L.; Stirpe, F.; Bonelli, M.; Petronini, P.G.; Brigotti, M. Shiga toxin 1 and ricin inhibit the repair of $\mathrm{H}_{2} \mathrm{O}_{2}$-induced DNA single strand breaks in cultured mammalian cells. DNA Repair 2005, 4, 271-277. [CrossRef] [PubMed]

260. Circu, M.L.; Aw, T.Y. Reactive oxygen species, cellular redox systems, and apoptosis. Free Radic. Biol. Med. 2010, 48, 749-762. [CrossRef] [PubMed]

261. Zhang, C.; Gong, Y.; Ma,H.; An, C.; Chen, D.; Chen, Z.L. Reactive oxygen species involved in trichosanthin-induced apoptosis of human choriocarcinoma cells. Biochem. J. 2001, 355, 653-661. [CrossRef] [PubMed]

262. Ramsden, C.S.; Drayson, M.T.; Bell, E.B. The toxicity, distribution and excretion of ricin holotoxin in rats. Toxicology 1989, 55, 161-171. [CrossRef]

263. Xu, N.; Yuan, H.; Liu, W.; Li, S.; Liu, Y.; Wan, J.; Li, X.; Zhang, R.; Chang, Y. Activation of RAW264.7 mouse macrophage cells in vitro through treatment with recombinant ricin toxin-binding subunit B: Involvement of protein tyrosine, NF-kB and JAK-STAT kinase signaling pathways. Int. J. Mol. Med. 2013, 32, 729-735. [CrossRef] [PubMed]

264. Silverstein, A.M. The collected papers of Paul Ehrlich: Why was volume 4 never published? Bull. Hist. Med. 2002, 76, 335-339. [CrossRef] [PubMed]

265. Vitetta, E.S.; Thorpe, P.E.; Uhr, J.W. Immunotoxins: Magic bullets or misguided missiles? Immunol. Today 1993, 14, 252-259. [CrossRef]

266. Brinkmann, U.; Pastan, I. Immunotoxins against cancer. Biochim. Biophys. Acta 1994, 1198, 27-45. [CrossRef]

267. Weidle, U.H.; Tiefenthaler, G.; Schiller, C.; Weiss, E.H.; Georges, G.; Brinkmann, U. Prospects of bacterial and plant protein-based immunotoxins for treatment of cancer. Cancer Genomics Proteomics 2014, 11, 25-38. [PubMed]

268. Munir, I.; Naseer, R.; Saleem, M.; Mahmood, A.; Sultana, A. Immunotoxins, an Advance tool for Cancer Treatment: Review and update. Acta Pol. Pharm. Drug Res. 2018, 75, 1267-1277. [CrossRef]

269. Polito, L.; Djemil, A.; Bortolotti, M. Plant Toxin-Based Immunotoxins for Cancer Therapy: A Short Overview. Biomedicines 2016, 4, 12. [CrossRef] [PubMed]

270. Lambert, J.M.; Goldmacher, V.S.; Collinson, A.R.; Nadler, L.M.; Blättler, W.A. An immunotoxin prepared with blocked ricin: A natural plant toxin adapted for therapeutic use. Cancer Res. 1991, 51, 6236-6242.

271. Krolick, K.A.; Villemez, C.; Isakson, P.; Uhr, J.W.; Vitetta, E.S. Selective killing of normal or neoplastic B cells by antibodies coupled to the A chain of ricin. Proc. Natl. Acad. Sci. USA 1980, 77, 5419-5423. [CrossRef] [PubMed]

272. Bourrie, B.J.; Casellas, P.; Blythman, H.E.; Jansen, F.K. Study of the plasma clearance of antibody-Ricin-A-chain immunotoxins. Evidence for specific recognition sites on the A chain that mediate rapid clearance of the immunotoxin. Eur. J. Biochem. 1986, 155, 1-10. [CrossRef]

273. Fulton, R.J.; Uhr, J.W.; Vitetta, E. In Vivo Therapy of the BCL1 Tumor: Effect of Immunotoxin Valency and Deglycosylation of the Ricin A Chain. Cancer Res. 1988, 48, 2626-2631.

274. Blakey, D.C.; Watson, G.; Knowles, P.P.; Thorpe, P. Effect of chemical deglycosylation of ricin A chain on the in vivo fate and cytotoxic activity of an immunotoxin composed of ricin A chain and anti-Thy 1.1 antibody. Cancer Res. 1987, 47, 947-952.

275. Street, N.E.; Fulton, R.J.; Sanders, V.M.; Vitetta, E.S. Inhibition of the helper function of murine T cells with Fab'-anti-L3T4 ricin A chain immunotoxin. J. Immunol. 1987, 139, 1734-1738.

276. Li, C.; Yan, R.; Yang, Z.; Wang, H.; Zhang, R.; Chen, H.; Wang, J. BCMab1-Ra, a novel immunotoxin that BCMab1 antibody coupled to Ricin A chain, can eliminate bladder tumor. Oncotarget 2017, 8, 46704-46705. [CrossRef] 
277. Petros, R.A.; DeSimone, J.M. Strategies in the design of nanoparticles for therapeutic applications. Nat. Rev. Drug Discov. 2010, 9, 615-627. [CrossRef] [PubMed]

278. Parveen, S.; Misra, R.; Sahoo, S.K. Nanoparticles: A boon to drug delivery, therapeutics, diagnostics and imaging. Nanomedicine 2012, 8, 147-166. [CrossRef] [PubMed]

279. Nichols, J.W.; Bae, Y.H. Odyssey of a cancer nanoparticle: From injection site to site of action. Nano Today 2012, 7, 606-618. [CrossRef]

280. Skotland, T.; Iversen, T.-G.; Sandvig, K. Development of nanoparticles for clinical use. Nanomedicine 2014, 9, 1295-1299. [CrossRef] [PubMed]

281. Tekle, C.; van Deurs, B.; Sandvig, K.; Iversen, T.-G. Cellular trafficking of quantum dot-ligand bioconjugates and their induction of changes in normal routing of unconjugated ligands. Nano Lett. 2008, 8, 1858-1865. [CrossRef]

282. Iversen, T.-G.; Frerker, N.; Sandvig, K. Quantum dot bioconjugates: Uptake into cells and induction of changes in normal cellular transport. In Colloidal Quantum Dots for Biomedical Applications IV; International Society for Optics and Photonics: Bellingham, WA, USA, 2009; Volume 7189, p. 71890T.

283. Li, Y.; Liu, W.; Sun, C.; Zheng, M.; Zhang, J.; Liu, B.; Wang, Y.; Xie, Z.; Xu, N. Hybrids of carbon dots with subunit B of ricin toxin for enhanced immunomodulatory activity. J. Colloid Interface Sci. 2018, 523, 226-233. [CrossRef] [PubMed]

284. Díaz, R.; Pallarès, V.; Cano-Garrido, O.; Serna, N.; Sánchez-García, L.; Falgàs, A.; Pesarrodona, M.; Unzueta, U.; Sánchez-Chardi, A.; Sánchez, J.M.; et al. Selective CXCR4 ${ }^{+}$Cancer Cell Targeting and Potent Antineoplastic Effect by a Nanostructured Version of Recombinant Ricin. Small 2018, 14, 1800665. [CrossRef]

285. Audi, J.; Belson, M.; Patel, M.; Schier, J.; Osterloh, J. Ricin poisoning: A comprehensive review. JAMA 2005, 294, 2342-2351. [CrossRef]

286. Smallshaw, J.E.; Vitetta, E.S. Ricin Vaccine Development. In Ricin and Shiga Toxins: Pathogenesis, Immunity, Vaccines and Therapeutics; Mantis, N., Ed.; Current Topics in Microbiology and Immunology; Springer: Berlin/Heidelberg, Germany, 2012; pp. 259-272, ISBN 978-3-642-27470-1.

287. Porter, A.; Phillips, G.; Smith, L.; Erwin-Cohen, R.; Tammariello, R.; Hale, M.; DaSilva, L. Evaluation of a ricin vaccine candidate (RVEc) for human toxicity using an in vitro vascular leak assay. Toxicon 2011, 58, 68-75. [CrossRef]

288. Bascon, J.U. Vascular leak syndrome: A troublesome side effect of immunotherapy, Immunopharmacology, 39/3 (1998) 255. Immunopharmacology 1998, 39, 255-257.

289. Vance, D.J.; Rong, Y.; Brey, R.N.; Mantis, N.J. Combination of Two Candidate Subunit Vaccine Antigens Elicits Protective Immunity to Ricin and Anthrax Toxin in Mice. Vaccine 2015, 33, 417-421. [CrossRef] [PubMed]

290. Vance, D.J.; Mantis, N.J. Progress and Challenges Associated with the Development of Ricin Toxin Subunit Vaccines. Expert Rev. Vaccines 2016, 15, 1213-1222. [CrossRef]

291. Wahome, N.; Sully, E.; Singer, C.; Thomas, J.C.; Hu, L.; Joshi, S.B.; Volkin, D.B.; Fang, J.; Karanicolas, J.; Jacobs, D.J.; et al. Novel Ricin Subunit Antigens with Enhanced Capacity to Elicit Toxin-Neutralizing Antibody Responses in Mice. J. Pharm. Sci. 2016, 105, 1603-1613. [CrossRef]

292. Sully, E.K.; Whaley, K.J.; Bohorova, N.; Bohorov, O.; Goodman, C.; Kim, D.H.; Pauly, M.H.; Velasco, J.; Hiatt, E.; Morton, J.; et al. Chimeric plantibody passively protects mice against aerosolized ricin challenge. Clin. Vaccine Immunol. 2014, 21, 777-782. [CrossRef] [PubMed]

293. Yermakova, A.; Klokk, T.I.; Cole, R.; Sandvig, K.; Mantis, N.J. Antibody-Mediated Inhibition of Ricin Toxin Retrograde Transport. mBio 2014, 5, e00995-13. [CrossRef] [PubMed]

294. Herrera, C.; Vance, D.J.; Eisele, L.E.; Shoemaker, C.B.; Mantis, N.J. Differential neutralizing activities of a single domain camelid antibody (VHH) specific for ricin toxin's binding subunit (RTB). PLoS ONE 2014, 9, e99788. [CrossRef]

295. Vance, D.J.; Tremblay, J.M.; Rong, Y.; Angalakurthi, S.K.; Volkin, D.B.; Middaugh, C.R.; Weis, D.D.; Shoemaker, C.B.; Mantis, N.J. High-Resolution Epitope Positioning of a Large Collection of Neutralizing and Nonneutralizing Single-Domain Antibodies on the Enzymatic and Binding Subunits of Ricin Toxin. Clin. Vaccine Immunol. 2017, 24. [CrossRef]

296. Poon, A.Y.; Vance, D.J.; Rong, Y.; Ehrbar, D.; Mantis, N.J. A Supercluster of Neutralizing Epitopes at the Interface of Ricin's Enzymatic (RTA) and Binding (RTB) Subunits. Toxins 2017, 9, 378. [CrossRef] 
297. O'Hara, J.M.; Mantis, N.J. Neutralizing Monoclonal Antibodies against Ricin's Enzymatic Subunit Interfere with Protein Disulfide Isomerase-Mediated Reduction of Ricin Holotoxin In Vitro. J. Immunol. Methods 2013, 395, 71-78. [CrossRef]

298. Pincus, S.; Das, A.; Song, K.; Maresh, G.; Corti, M.; Berry, J. Role of Fc in Antibody-Mediated Protection from Ricin Toxin. Toxins 2014, 6, 1512-1525. [CrossRef]

299. Yermakova, A.; Mantis, N.J. Protective Immunity to Ricin Toxin Conferred by Antibodies against the Toxin's Binding Subunit (RTB). Vaccine 2011, 29, 7925-7935. [CrossRef] [PubMed]

300. Yermakova, A.; Mantis, N.J. Neutralizing activity and protective immunity to ricin toxin conferred by B subunit (RTB)-specific Fab fragments. Toxicon 2013, 72, 29-34. [CrossRef] [PubMed]

301. Yermakova, A.; Vance, D.J.; Mantis, N.J. Sub-domains of ricin's B subunit as targets of toxin neutralizing and non-neutralizing monoclonal antibodies. PLoS ONE 2012, 7, e44317. [CrossRef]

302. Cherubin, P.; Quiñones, B.; Teter, K. Cellular recovery from exposure to sub-optimal concentrations of $A B$ toxins that inhibit protein synthesis. Sci. Rep. 2018, 8, 2494. [CrossRef] [PubMed]

303. Lin, J.-Y.; Tserng, K.-Y.; Chen, C.-C.; Lin, L.-T.; Tung, T.-C. Abrin and Ricin: New Anti-tumour Substances. Nature 1970, 227, 292. [CrossRef] [PubMed]

304. Lin, J.Y.; Chang, Y.C.; Huang, L.Y.; Tung, T.C. The cytotoxic effects of abrin and ricin on Ehrlich ascites tumor cells. Toxicon 1973, 11, 379-381. [CrossRef]

305. Fodstad, O.; Kvalheim, G.; Godal, A.; Lotsberg, J.; Aamdal, S.; Høst, H.; Pihl, A. Phase I study of the plant protein ricin. Cancer Res. 1984, 44, 862-865.

306. Davies, M.P.A.; Barraclough, D.L.; Stewart, C.; Joyce, K.A.; Eccles, R.M.; Barraclough, R.; Rudland, P.S.; Sibson, D.R. Expression and splicing of the unfolded protein response gene XBP-1 are significantly associated with clinical outcome of endocrine-treated breast cancer. Int. J. Cancer 2008, 123, 85-88. [CrossRef]

307. Koong, A.C.; Chauhan, V.; Romero-Ramirez, L. Targeting XBP-1 as a novel anti-cancer strategy. Cancer Biol. Ther. 2006, 5, 756-759. [CrossRef]

(C) 2019 by the authors. Licensee MDPI, Basel, Switzerland. This article is an open access article distributed under the terms and conditions of the Creative Commons Attribution (CC BY) license (http://creativecommons.org/licenses/by/4.0/). 